This article has been accepted for publication in the Modern Law Review, and is scheduled to appear in (2019) 82:1.

\title{
UK Abortion Law: Reform Proposals, Private Members' Bills, Devolution and the Role of the Courts
}

\section{Robert Brett Taylor and Adelyn L M Wilson}

Lecturer in Law and Senior Lecturer in Law

University of Aberdeen School of Law

\begin{abstract}
Abortion - Devolution - Private Members' Bills - Convention Rights - Judicial Review
\end{abstract}
\begin{abstract}
UK abortion law remains unsettled, and is subject to on-going controversy and reform. This article offers for the first time a comprehensive critique of the reforms which have been implemented or proposed since 2016. First, it will examine reforms proposed in both Houses of Parliament at Westminster. This article will contextualise these reforms within a wider public law analysis, showing both that the complex parliamentary processes relating to Private Members' Bills have frustrated reform attempts, and that these attempts have been contradictory in their aims between the two Houses. Secondly, it will examine the unique positions of Northern Ireland, Scotland and Wales. In doing so, it will show the extent to which the different devolutionary settlements have influenced both the reforms themselves and the nature of executive involvement. Finally, this article will examine the potential impact of the courts on abortion law following Re Northern Ireland Human Rights Commission's Application for Judicial Review [2018] UKSC 27. It will show that the Supreme Court's reframing of the debate in human rights terms is likely to affect abortion law, not only in Northern Ireland, but in the whole of the UK.
\end{abstract}

The 50th anniversaries of the enactment and subsequent commencement of the Abortion Act 1967 fell in October 2017 and April 2018 respectively. This Act allows abortions to be conducted legally in England, Wales and Scotland in certain circumstances. These anniversaries have not been marked with complacency. Rather, the current and previous parliamentary sessions have witnessed several attempts to reform law and practice in this area in all three of the constituent nations affected by the Act. These reforms have been proposed both by primary legislation and through executive action; one of the latter reforms is now subject to an on-going judicial review action. Meanwhile two judgements have been handed down by the Supreme Court within the last year in light of the comparative restrictiveness of the law in Northern Ireland. Calls have been made in Westminster to liberalise the law in Northern Ireland, following both these cases and the result of the referendum in the Republic of Ireland held in May 2018 which enabled the Irish Parliament to legislate on that nation's similarly restrictive abortion laws.

The recent reforms and current proposals have received little acknowledgement within the legal community. Yet they are of considerable importance. Cumulatively the decisions of all three branches 
of the state-executive, legislature and judiciary-will make considerable changes to the availability of abortion in the four constituent nations of the UK. The proposals also reflect some of the most prominent debates on abortion: medical paternalism versus patient autonomy, self-administration of misoprostol in a non-clinical setting, the number of weeks of gestation during which abortion remains appropriate, and protection of foetal rights. Therefore, whatever the outcome of these particular proposals for reform, it is likely that the three branches of the UK state will witness further debate on the issues advanced therein in due course.

The changes also have importance for UK public law in several respects, only some of which can be examined within the scope of this article. First, the law of abortion has traditionally been one in which the Westminster Government has avoided legislating. Substantive reform has instead previously been achieved or proposed by backbenchers through the Private Members' Bills procedure, ${ }^{1}$ or as amendments to an existing Government Bill which were inspired at least in part by a Private Members' Bill. ${ }^{2}$ The recent proposals for reform highlight the inadequacies of these processes, which in turn raises questions about the democratic processes within Westminster. ${ }^{3}$ Further democratic and constitutional difficulties arise in that backbenchers in both Houses of Parliament are seeking to reform the law in contrary ways. A liberalising agenda has found favour in the House of Commons in both the current and previous session: one Bill with this intended effect was introduced in the previous Parliament but did not progress into law, and another is shortly anticipated in the current session. However, a less liberal agenda has found favour in the House of Lords, where two Bills have been introduced in this current session which would restrict abortion services in England and Wales. ${ }^{4}$

Secondly, the current reforms highlight uncertainties, inconsistencies and tensions in the devolutionary settlements of Northern Ireland, Scotland and Wales. The differences in the devolutionary settlements with respect to the law of abortion lack comparative study but are considerable. This could have a significant impact on the legal powers and political options available to the UK's four legislatures in the months to come. The most recent decision of the UK Supreme Court on the law of abortion in Northern Ireland, however, suggests that these differences may soon be subject to a judicially-imposed minimum standard to ensure compliance with the European Convention on Human Rights. ${ }^{5}$ This may force greater uniformity to the law of abortion across the UK in the near future.

This article will review for the first time the recent legislative proposals and executive actions, highlighting the reforms to UK abortion law that they intend to make. It will examine critically the rationale behind these reforms-both declared explicitly and inferable-as well as their potential impact and connection to wider constitutional change. This article, therefore, intends to contribute to

\footnotetext{
Unless otherwise stated, all URLs were last accessed 22 June 2018. The authors would like to thank Roderick Paisley, Heather Green and Isla Callander of the University of Aberdeen for reading an earlier draft of this article, and to the Modern Law Review editors and the anonymous reviewers for their comments.

1 John Keown, Abortion, Doctors and the Law: Some Aspects of the Legal Regulation of Abortion in England from 1803 to 1982 (Cambridge: Cambridge University Press, 1988), ch 6; David Paintin, Abortion Law Reform in Britain 1964-2003: A Personal Account (Stratford-upon-Avon: British Pregnancy Advisory Service, 2015), chs 7-8.

2 The Human Fertilisation and Embryology Act 1990 Act, on which see below.

${ }^{3}$ See also similar complaints on previous reform attempts, S. Sheldon, 'The Decriminalisation of Abortion: An Argument for Modernisation' (2016) 36 Oxford Journal of Legal Studies 334-365, 364-365.

${ }^{4}$ It is not the first time that legislation on abortion has been introduced to the two different Houses within the same session, see e.g. in 2014-15 when the Abortion Act 1967 (Amendment) Bill [HL] 2014-15 was introduced in the House of Lords while the Abortion (Sex-Selection) Bill 2014-15 was introduced to the House of Commons. ${ }^{5}$ Re Northern Ireland Human Rights Commission's Application for Judicial Review [2018] UKSC 27.
} 
the on-going discussions surrounding reform to abortion law, whilst providing readers with a greater understanding of the background context to this debate as it progresses.

First, it will set out the current legislative framework on the law of abortion in England, Scotland and Wales, which is found in the Abortion Act 1967 as amended. This Act provides a shared context for the recent reforms and proposals in these three constituent nations and also for much of the discussion with respect to Northern Ireland.

Secondly, this article will then examine the most recent attempts by backbenchers in both the House of Commons and the House of Lords to reform the Abortion Act. Three separate Private Members' Bills have been introduced within the last two years and another is now anticipated. This article will: identify the rationale behind the Bills where possible, analyse the evidence led in their support, examine the changes to the law proposed and the mechanisms by which this would be achieved, and comment on their possible impact if implemented into law. This new understanding of the Bills comes at a critical time in the legislative process, given that a new Bill is expected shortly in the House of Commons and two Bills in the House of Lords currently await their next reading.

To complement that analysis, this article will also take the opportunity to explain the parliamentary procedure for Private Members' Bills in the two Houses. This aspect of public law has been subject to little examination in the academic literature, and the leading works (such as Erskine May) are outdated since recent changes in procedure in both Houses. ${ }^{6}$ This is a problematic lacuna generally but presents a particular challenge to the study of the law of abortion because this area has been advanced largely by Private Members' Bills. Therefore, in providing this procedural context, this article addresses an important lack in the current academic literature on the UK's public law as well as necessary context for understanding the recent reforms in the law of abortion.

Thirdly, this article will thereafter examine the devolution of the law of abortion to the other three constituent nations: Northern Ireland, Scotland and Wales. It will highlight the inconsistencies in approach to this area of law between these devolutionary settlements. It will examine the current discussions in Westminster on legislating for Northern Ireland, commenting on both the legality of such a possibility, as well as the impact of doing so for the wider legislative reform packages scheduled for this parliamentary session. It will also examine the Scottish and Welsh Governments' recent uses of delegated powers in this area of law.

Finally, the article will look briefly at the recent decision of the UK Supreme Court on the compatibility of abortion law in Northern Ireland with the European Convention on Human Rights. ${ }^{7}$ In so doing, it will be shown that that the decision has the potential to shift the debate on abortion away from politicians and towards judges. In doing so, it raises questions over both the legitimacy and sustainability of current variations in abortion law across the UK as a consequence of devolution.

Overall this article will acknowledge that this issue is still subject to moral debate and remains an unsettled area of law. It does not advance a moral position, but submits that (regardless of one's view of abortion) full, open and informed debate of legislative reform is required for the exercise of democratic rule.

\footnotetext{
${ }^{6}$ The most notable change in the House of Commons since the last edition of Erskine May has been the introduction of additional legislative stages for English Votes for English Laws, on which procedural changes see HC 410 (2015), HC 189 (2016). The House of Lords meanwhile have since introduced a ballot system for Private Members' Bills (on which, see below) and three successive revised versions of the Companion to the Standing Orders and Guide to the Proceedings of the House of Lords (2010, 2013, 2017).

${ }^{7}$ Re Northern Ireland Human Rights Commission's Application for Judicial Review [2018] UKSC 27.
} 
This article has been accepted for publication in the Modern Law Review, and is scheduled to appear in (2019) 82:1.

\section{THE ABORTION ACT 1967}

Before examining the current reforms, it is necessary to first describe briefly the underlying criminal law in England, Wales and Scotland, and to explain the exceptions to this provided by the Abortion Act 1967. Abortion, and certain connected activities, are still illegal in England and Wales under sections 58-59 of the Offences Against the Person Act 1861 and section 1 of the Infant Life Preservation Act $1929 ;^{8}$ before the 1967 Act an exception to this illegality was only made where the pregnant woman's life was threatened by the impact of the pregnancy on her mental or physical health in $R v$ Bourne. ${ }^{9}$ The offence of foetal destruction continues to be prosecuted, if rarely. ${ }^{10}$

In Scotland, abortion was traditionally illegal by common law unless the pregnancy posed a risk to the life or health of the woman; in Aberdeen particularly a liberal approach to this test allowed abortions to be accessible. ${ }^{11}$

The Abortion Act 1967 was introduced to make lawful abortions accessible in England, Wales and Scotland in some circumstances. It introduced exceptions against prosecution for the aforementioned offences of abortion or child destruction, but did not remove those underlying offences. It has only once been substantively amended, namely by the Human Fertilisation and Embryology Act 1990. The relevant provisions of this latter Act were introduced in anticipation of so-called 'medical' abortion becoming possible by pharmaceutical intervention. ${ }^{12}$ The 1967 Act as thus amended constitutes the principal legal framework within which abortion operates in these three constituent nations.

Section 1 of the Act sets down four requirements which must be met for an abortion to be lawful. Outwith these requirements, abortion remains unlawful under the 1861 and 1929 Acts in England and Wales and under the common law in Scotland.

First, section $1(1)$ requires that the treatment for abortion is performed 'by a registered medical practitioner'. Sections 3-4 of the Medical Act 1983 normally interprets 'registered medical practitioner' as being a doctor suitably trained and registered with the General Medical Council. However, the interpretation of this phrase was extended to those participating in the abortion process under the doctor's general supervision in Royal College of Nurses of the United Kingdom v Department for Health and Social Services [1981] AC 800; the legal protections under the Act are therefore available to all members of the treatment team.

Secondly, section 1(1) requires that the abortion must be approved by two registered medical practitioners 'in good faith'. Section 1(4) provides an exception where one registered medical

\footnotetext{
${ }^{8}$ For a detailed discussion of these Acts, see eg Sheldon $\mathrm{n} 2$ above, 337-342; S. Sheldon, 'British Abortion Law: Speaking from the Past to Govern the Future' (2016) 79 MLR 283-316.

${ }^{9}$ [1939] 1 KB 687.

${ }_{10} R \quad V$ Catt, Crown Court of Leeds, 17 September 2012 (unreported), accessed at https://www.judiciary.gov.uk/wp-content/uploads/JCO/Documents/Judgments/sarah-louise-catt-sentencingremarks-17092012.pdf on 8 May 2018. Note that the 1861 Act was not directly mentioned in the sentencing remarks and the 1929 Act was explicitly not the ground on which the charge was laid. See also the appeal on sentencing: $R v$ Catt [2014] 1 Cr App R (S.) 35.

${ }^{11}$ G. Davis and R. Davidson, "'A Fifth Freedom" or "Hideous, Atheistic Expediency"? The Medical Profession and Abortion Law Reform in Scotland, c.1960-1975' (2006) 50 Medical History 29-48, 31-35; D. Baird, 'Sterilization and Therapeutic Abortion in Aberdeen' (1967) 113 British Journal of Psychiatry 701-709; J. Brown, 'Scotland and the Abortion Act 1967: Historic Flaws, Contemporary Problems' [2015] Juridical Review 135-155.

${ }^{12}$ For a critical account of the changes made at this time, see A. Grubb, 'The New Law of Abortion: Clarification or Ambiguity?' [1991] Criminal Law Review 659-670.
} 
This article has been accepted for publication in the Modern Law Review, and is scheduled to appear in (2019) 82:1.

practitioner believes in good faith 'that the termination is immediately necessary to save the life or to prevent grave permanent injury to the physical or mental health of the pregnant woman.'

Thirdly, section 1(3) requires that the abortion is conducted in approved premises. These premises explicitly include National Health Service (NHS) hospitals or 'a place approved for the purposes of this section by the Secretary of State'. The wording if not the substance of this section has been updated periodically to reflect administrative changes in NHS and government ministerial structures. ${ }^{13}$ Section 1(3A) was introduced by section 37 of the 1990 Act to allow the Secretary of State to approve a 'class of places' rather than an individual location. The power of approval under section 1(3) was interpreted as enabling a licensing system, which is now well established. The power under section $1(3 \mathrm{~A})$ has been implemented only once, by the Scottish Government, but it will be shown elsewhere that the nature of the power granted has been misunderstood. ${ }^{14}$ Section $1(4)$ again provides exemption from the premises restriction in what might be considered emergency circumstances.

Finally, section 1(1) permits abortion to be performed lawfully only if it is on one of four grounds that relate to the pregnancy itself. The Act originally allowed abortion only when either the pregnancy posed a greater risk to the mother's mental or physical health or to her existing family than abortion, or there was 'substantial risk' that the foetus if born would 'be seriously handicapped'. These grounds were amended by section 37 of the 1990 Act, which substituted the original section with new provisions. Section 1(1)(a) of the 1967 Act as amended retains the original first ground, but now specifies a limit of 24 weeks' gestation. Section $1(1)(d)$ retains the second original ground unchanged. Two new grounds were also added: section 1(1)(b) applies when the abortion meets the higher test of preventing 'grave permanent injury' to the pregnant woman's mental or physical health; section $1(1)(c)$ allows for the situation where the pregnancy poses a risk to her life; neither of these new provisions are time-bound. Section 1(2) allows the two registered medical practitioners to take account of the woman's 'actual or reasonably foreseeable environment' when deciding whether any of these four grounds apply.

The other sections of the Act are less relevant to the focus of this article. Section 2 includes reporting requirements and provides the Secretary of State with delegated legislative authority to regulate the reporting process by negative statutory instrument. Section 3 sets out the application of the Act to the armed forces. Section 4(1) allows a person to decline to participate in the treatment for abortion if they have a conscientious objection; this right is limited to those who participate directly in the treatment process rather than in associated administrative duties; ${ }^{15}$ section $4(2)$ removes the right to conscientious objection in cases of emergency. Section 5 explains the operation of the Act relative to the Infant Life (Preservation) Act 1929, and makes it unlawful to procure a miscarriage except as allowed by section 1 of the 1967 Act. Sections 6 and 7 set out interpretations as well as the Act's extent, commencement and short title.

\section{RECENT REFORM FOR LIBERALISATION IN THE HOUSE OF COMMONS}

\footnotetext{
${ }^{13}$ See for example sch. 1, para. 17(1) of the Health Services Act 1980.

${ }^{14}$ On the history of these two subsections, the licensing system under section $1(3)$ and the nature of the powers under section 1(3A), see R. Taylor and A. Wilson, 'Allowing Home Abortion in the UK: Executive orders, Delegated Legislation and the Rule of Law' (working title, forthcoming).

${ }^{15} R$ v Salford Health Authority, Ex p Janaway [1989] AC 537; Doogan and another v Greater Glasgow and Clyde Health Board [2015] AC 640.
} 
This article has been accepted for publication in the Modern Law Review, and is scheduled to appear in (2019) 82:1.

The current and previous parliamentary sessions have witnessed a call for liberalisation of the law of abortion in the House of Commons. This present move for reform has been led in the first instance by the Labour MP, Diana Johnson, with more recent support in this leading role being given by her fellow Labour MP, Stella Creasy. The majority of those in attendance or contributing to the discussions in the House of Commons have expressed broad support for the principle of liberalising the law in England and Wales, although this has been controversial. Johnson and Creasy have thus indicated that it is their intention to seek legislative reform the law in the near future, as will be discussed below.

Any new Bill introduced in the present parliamentary session is unlikely to be successfully implemented into law, and indeed reform by primary legislation was attempted by Diana Johnson in the previous session. This lack of success is explained in part by reference to the parliamentary procedure in Westminster: the Standing Orders of the House of Commons make the enactment of Bills proposed by backbenchers such as Johnson and Creasy highly challenging.

Bills introduced into either House of Parliament can be understood as: Public Bills to change the law as it applies to the general public, Private Bills to change the law as it applies to specific individuals or organisations, or Hybrid Bills with elements of both prior categories. ${ }^{16}$ Public Bills are the most common type of primary legislation, and may be categorised further into 'Government Bills' introduced by Government Ministers and Private Members' Bills (PMBs) introduced by backbenchers. The House of Commons Standing Order No. 14(1) stipulates that '[s]ave as provided in this order, government business shall have precedence at every sitting'. The Government thus has legislative initiative in the Commons, and Government Bills accordingly dominate the legislative timetable. Yet abortion has traditionally been an area of law in which the Government has resisted introducing Bills, probably due to the contentious nature of the topic which is likely to divide both party members and the electorate.

The Abortion Act 1967 was famously a PMB, introduced by the Liberal MP David Steel. The subject matter of PMBs is said to be unrestricted, with the exception of tax or public expenditure-creating Bills. ${ }^{17}$ PMBs are often associated with 'matters of conscience', ${ }^{18}$ of which the 1967 Act is often cited as an example. Yet, contrary to popular perception, the majority of PMBs are said to be uncontroversial. ${ }^{19}$ This makes the 1967 Act, as well as the legislation proposed by Johnson and Creasy, an exception to the normal rule.

This article will examine Diana Johnson's failed attempt in the previous Parliament to introduce primary legislation via two different mechanisms for introducing PMBs: the Ballot process and the Ten Minute Rule. The Standing Orders relevant to these procedures have received little comment in the academic literature, so this article will take the opportunity to address that lack. It will then examine the promise of forthcoming legislation made by Johnson and Creasy. It will construct the likely content and approach of the Bill from Johnson's comments in the previous parliamentary session, as well as remarks made in two debates moved by Johnson and Creasy during the present parliamentary session.

\footnotetext{
${ }^{16}$ A. Le Sueur, M. Sunkin and J. E. K. Murkens, Public Law: Text, Cases and Materials (Oxford: Oxford University Press, 3rd edn, 2016), 407-408.

${ }^{17}$ House of Commons, Commons Briefing Note: Private Members' Bills: Ballot 2016 (2016), para 9

at https://www.parliament.uk/documents/commons-information-office/Commons-Briefing-note-7-ballotprivate-members-bills-2016.pdf.

${ }^{18}$ H. Fenwick, G. Phillipson and A. Williams, Text, Cases and Materials on Public Law and Human Rights (London: Routledge, 4th edn, 2017), 330.

${ }^{19}$ House of Lords, Library Briefing: Private Member's Bills in the House of Lords (2017), para 2.2 at https://researchbriefings.parliament.uk/ResearchBriefing/Summary/LLN-2017-0058.
} 
This article has been accepted for publication in the Modern Law Review, and is scheduled to appear in (2019) 82:1.

It will finally reflect on the likelihood of any primary legislation being enacted on this matter during the present parliamentary session.

\section{Attempts to reform the law in the 2016-17 parliamentary session}

Private Members Bills are most commonly introduced into the House of Commons via a ballot system regulated by Standing Order No. 14(11). Backbench MPs wishing to introduce primary legislation can enter their names into a ballot; 450-500 have entered the two most recent ballots. Twenty names are drawn in the ballot on the second sitting Thursday of the parliamentary session. ${ }^{20}$ Those $20 \mathrm{MPs}$ are accorded the opportunity to introduce a PMB, commonly known as a 'Ballot Bill', in reverse order to that in which they were drawn. Standing Order No. 14(9) sets down that 13 Fridays are set aside for consideration of PMBs, of which the first seven prioritise Ballot Bills. Only the seven most highly prioritised Ballot Bills are in practice likely to have a full day's debate. As will be shown below, the parliamentary time accorded to them means that Ballot Bills are more likely to be enacted than other types of PMB. Indeed, the Abortion Act 1967 was introduced as a Ballot Bill, David Steel having received the third most highly-prioritised place on the Ballot that year. ${ }^{21}$

Johnson unsuccessfully entered the ballot in the 2016-17 parliamentary session. ${ }^{22}$ Little further can be learned from the ballot about her motivation in entering the list. An MP does not specify the topic on which he or she wishes to bring primary legislation, and indeed (as was also the case with David Stee ${ }^{23}$ ) this is often chosen afterwards after lobbying by interested parties both within and outwith Parliament. ${ }^{24}$

An MP who is unable to introduce a Ballot Bill may seek two alternative routes to presenting draft legislation to the House. First, the MP could seek to introduce a PMB via a 'presentation' under Standing Order No. 57; the MP must give notice but not seek leave from the House. This involves introducing the title of the Bill only, without any opportunity for debate. Secondly, the MP could request leave under Standing Order No. 23 to introduce a PMB under the 'Ten Minute Rule'. This Rule allows MPs 10 minutes to speak on any matter of their choosing; an opponent may also speak for 10 minutes.

Diana Johnson introduced a Bill in the 2016-17 parliamentary session under the Ten Minute Rule. She initially sought leave to introduce on 26 October 2016 'a bill to amend sections 58 and 59 of the Offences Against the Person Act 1861 to decriminalise consensual abortions; and for connected

\footnotetext{
${ }^{20} 500$ members are listed on both the 2016-17 and 2017-19 ballot papers, but only 458 and 461 MPs respectively were entered into the draws on the day [House of Commons, 'Members Entering for the Ballot for Bills, as at Tuesday 24 May 2016' at https://publications.parliament.uk/pa/cm201617/cmagenda/bfb160525.pdf; House of Commons, 'Members Entering for the Ballot for Bills, as at Wednesday 28 June 2017' at https://publications.parliament.uk/pa/cm201719/cmagenda/bfb 170629.pdf;

Parliament, 'Private Members' Bill Ballot, Thursday 26 May 2016' (video recording) at https://parliamentlive.tv/Event/Index/c22db98e-d6ee-42db-8b82-afe72b6c8602;

Parliament, 'Private Members' Bill Ballot, Thursday 29 June 2017' (video recording) at https://parliamentlive.tv/event/index/15c3528f-2fd2-4123-9ed6-b481c8b3514e].

${ }^{21}$ David Steel, 'Abortion Reform 1967', Liberal Democrat History Group Newsletter (14 March 1997), 12.

22 House of Commons, 'Members Entering for the Ballot for Bills, as at Tuesday 24 May 2016' n 17 above; Parliament, 'News: Private Members' Bill Ballot: 26 May 2016' at https://www.parliament.uk/business/news/2016/may/private-members-bill-ballot-26-may-2016-/.

23 Steel $\mathrm{n} 18$ above.

24 A. Brazier and R. Fox, 'Enhancing the Backbench MP's Role As a Legislator: The Case for Urgent Reform of Private Members Bills' (2010) 63 Parliamentary Affairs 201-211, 202. See also House of Commons Information Office, 'Factsheet L1: Private Members' Bill Procedure' (2010), 3 at https://www.parliament.uk/documents/commons-information-office/l02.pdf.
} 
This article has been accepted for publication in the Modern Law Review, and is scheduled to appear in (2019) 82:1.

purposes'. However, she later withdrew her motion to introduce that Bill. ${ }^{25}$ She subsequently sought leave again, and on 13 March 2017 introduced the Reproductive Health (Access to Terminations) Bill 2016-17, the stated aim of which was 'to regulate the termination of pregnancies by medical practitioners and to repeal certain criminal offences relating to such terminations'. ${ }^{26}$

The Bill's introduction was opposed by the Conservative MP Maria Caulfield. It is unusual for an argument to be made against the introduction of a Bill. Of the 49 PMBs introduced under the Ten Minute Rule in the 2016-17 parliamentary session, only seven (including Johnson's Bill) were subject to an opposing argument. More unusual still, when the Speaker of the House of Commons put to the House the motion that Johnson be given leave to introduce the Bill, the calls for 'aye' and 'nay' were sufficiently close that the House went into division. The subsequent vote allowed the Bill to be introduced, at 172 in favour and 142 against. The Bill was therefore introduced and was scheduled for its second reading on 24 March 2017. The division of the House over whether to allow a Bill to be introduced is rare. This was the only Bill brought under the Ten Minute Rule in the 2016-17 parliamentary session over which the House was divided.

The text of the Bill introduced by Diana Johnson was not published before 24 March 2017. Standing Order No. 14(14) requires that the text of a proposed Bill must be published only by the commencement of business the sitting day prior to the scheduled second reading. However, it is common for PMBs brought under the Ten Minute Rule procedure to not be subsequently supported with the publication of a Bill text. Indeed, in the 2016-17 session, Bill texts were published for only 15 (31 per cent) of the 49 PMBs introduced under this rule.

The day Johnson's Bill was scheduled for its second reading was Friday 24 March 2017, which was the next and final Friday scheduled for PMBs in that parliamentary session. More than 70 PMBs had been listed for that day's debate in advance, but those 34 for which no text had been published (including Johnson's) could not progress so were removed. ${ }^{27}$ Most of the remaining 70 were subject to either debate or simply either progressed or deferred by simple declaration. ${ }^{28}$ The deferral was notional: the Bills were in reality abandoned. The purpose of this ceremony is merely to close out the PMBs still before the House on the final day reserved for that type of parliamentary business. PMBs introduced in neither House can be carried forward into a new parliamentary session. ${ }^{29}$

The failure of Johnson's Bill to progress was to be expected. Since the 1997-98 parliamentary session, typically 15 to 25 per cent of Ballot Bills achieved Royal Assent. For an even longer period, normally no or very few Bills introduced under the Ten Minute Rule or as Presentation Bills were enacted into law. ${ }^{30} \mathrm{~A}$ closer look at the progression stages of PMBs shows that most progress no further than their first reading. The stages reached by Government Bills and PMBs (overall and by method of introduction) introduced to the House of Commons in the parliamentary session 2016-17 are shown in table one below. That table shows that only a small proportion of the PMBs introduced under the Ten Minute Rule progressed beyond the first reading, and a very small number were enacted into law.

\footnotetext{
${ }^{25}$ HC OP 37 (14 September 2016), part 2, 29 [cf HC OP 36 (13 September 2016), part 2, 30]; HC OP 39 (10 October 2016), part 2, 24.

${ }^{26} \mathrm{HC}$ Deb vol 623 cols 26-33 13 March 2017, quotation at col 26.

${ }^{27}$ HC OP 127 (20 March 2017), part 2, 23-31; cf HC OP 131 (24 March 2017), part 1, 3-6.

${ }^{28}$ HC Deb 24 March 2017 vol 623 cols 1043-1112.

${ }^{29} \mathrm{cf}$ Government Bills under Standing Order No. 80A (Appendix 1) and Standing Order No. $80 \mathrm{~B}$.

${ }^{30}$ House of Commons Library Briefing Paper 02283 (3 July 2017), 3; H. Marsh and D. Marsh, 'Tories in the Killing Fields? The Fate of Private Members' Bills in the 1997 Parliament' (2002) 8 Journal of Legislative Studies 91-112, 96.
} 
This article has been accepted for publication in the Modern Law Review, and is scheduled to appear in (2019) 82:1.

\begin{tabular}{|c|c|c|c|c|c|c|c|c|}
\hline \multirow{2}{*}{\multicolumn{2}{|c|}{ Bill type }} & \multirow{2}{*}{$\begin{array}{l}\text { Total Bills } \\
\text { introduced } \\
\text { (given first } \\
\text { reading) }\end{array}$} & \multicolumn{2}{|c|}{$\begin{array}{l}\text { Bills reaching } \\
\text { second reading }\end{array}$} & \multicolumn{2}{|c|}{$\begin{array}{l}\text { Bills reaching } \\
\text { Committee Stage }\end{array}$} & \multicolumn{2}{|c|}{$\begin{array}{l}\text { Bills reaching } \\
\text { Royal Assent }\end{array}$} \\
\hline & & & No. & $\%$ & No. & $\%$ & No. & $\%$ \\
\hline \multicolumn{2}{|c|}{ Total both types of Bills } & 134 & 45 & $34 \%$ & 31 & $23 \%$ & 26 & $19 \%$ \\
\hline \multicolumn{2}{|c|}{ Government Bills } & 21 & 21 & $100 \%$ & 21 & $100 \%$ & 18 & $86 \%$ \\
\hline \multirow{4}{*}{ PMBs } & Total PMBs & 112 & 26 & $23 \%$ & 12 & $11 \%$ & 8 & $7 \%$ \\
\hline & 10 Minute Rule & 49 & 2 & $4 \%$ & 1 & $2 \%$ & 1 & $2 \%$ \\
\hline & Presentation Bills & 43 & 9 & $21 \%$ & 4 & $9 \%$ & 2 & $5 \%$ \\
\hline & Ballot Bills & 20 & 15 & $75 \%$ & 7 & $35 \%$ & 5 & $25 \%$ \\
\hline
\end{tabular}

Table one: Showing legislative stages reached by Government Bills and PMBs (but not Private or Hybrid Bills) introduced in the House of Commons during the parliamentary session 2016-17.

PMBs are supposed to provide backbench MPs with the opportunity to have legislation enacted rather than the Government. It is sadly ironic, therefore, that PMBs are unlikely to become law without the support of Government. As Fenwick, Phillipson and Williams observe, 'usually Bills can only become law if they have support from the Government, which can ensure that the Bill has adequate time to pass all stages' ${ }^{31}$ Some of the most well-known and controversial PMBs enacted, including again the Abortion Act 1967, ${ }^{32}$ in fact had the support of the Government of the day. ${ }^{33}$ Indeed, the Abortion Act was enacted after very extended debate in the chambers and committees; its exceptional quantity of debate can be attributed to the support of the Government. Although Brazier and Fox argue that Government support should not overshadow the efforts of individual MPs in getting PMBs passed, ${ }^{34}$ the hand of Government in the PMB process cannot be understated. First, support for backbench MPs in researching and drafting their proposed Bills is severely limited, hence the need for either governmental or external backing. ${ }^{35}$ Indeed, in some cases, Governments offer their backbench MPs successful in the ballot what is known as a 'Handout Bill'-a Government Bill in all but name, to which the Government of the day is merely unable to allocate sufficient parliamentary time. ${ }^{36}$ Marsh and Marsh noted that many of the PMBs which were enacted in the 1990s were Handout Bills, even with organised resistance to such Bills from the Opposition benches. ${ }^{37}$ Secondly, 13 Fridays in each parliamentary session is insufficient time for the quantity of PMBs introduced.

The lack of Government support would be one factor in the failure of the various attempts to limit the availability of abortion by PMB since $1967 .{ }^{38}$ This poor chance of success means that PMBs introduced under the Ten Minute Rule are not often taken seriously by MPs as legislative efforts. This has been explicitly recognised by MPs in the chamber. The Conservative MP David Burrowes stated the following when introducing his Child Maintenance (Assessment of Parents' Income) Bill under the Ten

\footnotetext{
${ }^{31}$ H. Fenwick, G. Phillipson and A. Williams, Text, Cases and Materials on Public Law and Human Rights, 4th edn (Routledge, 2017), 330. See also Brazier and Fox n 21 above, 204; Marsh and Marsh n 27 above, 100-104.

${ }^{32}$ HL Deb 16 February 1998 vol 586 c6WA.

33 Brazier and Fox n 21 above, 205.

34 ibid 203.

35 ibid, 202-203.

${ }^{36}$ HC 684 (2016), para 18; Marsh and Marsh n 27 above, passim.

${ }^{37}$ Marsh and Marsh n 27 above, 104-110.

${ }^{38}$ See for accounts of some initial attempts, Keown n 1 above, ch 6; Paintin n 1 above, ch 7-8. Cf the 1990 Act's being influenced in part by the Houghton Bill, Paintin $n 1$ above, 96-97.
} 
This article has been accepted for publication in the Modern Law Review, and is scheduled to appear in (2019) 82:1.

Minute Rule on 19 April 2017, 'I appreciate that this Bill is probably the least likely ever to become law during its parliamentary Session. ... If you will indulge me, Mr Speaker, let me make a bid for this issue to be in the Conservative manifesto, and let me make an early and most public bid for its inclusion in the next Queen's speech. ${ }^{39}$ The particular circumstances of this Bill's introduction were unusual: the following item of business was Theresa May's call for an early General Election. However, it is notable that Burrowes used the opportunity of the introduction of a Bill to make a call for change to the political rather than the legal agenda. This example is part of the wider trend noted by Brazier and Fox, who have suggested that both the Ten Minute Rule and the Presentation Rule 'are mainly used as a means of attracting publicity, raising public and parliamentary awareness of an issue and taking the political temperature of Parliament'. ${ }^{40}$ Hence the low number of Bills introduced under this Rule for which a text is thereafter published, which trend in turn exacerbates the low progressions rates noted in table one.

It could be suggested that Johnson's Bill might be subject to such criticism, having been introduced late in the parliamentary session and not followed with a text. However, whether or not that Bill was in itself taken seriously, it is clear that Johnson and Creasy are determined to produce legislative change through sustained attention on the issue.

\section{Attempts to reform the law in the present 2017-19 session}

Johnson and Creasy both entered the Ballot for the present session unsuccessfully. ${ }^{41}$ However, they have nevertheless raised awareness of the perceived need for reform by moving motions for debate on the law of abortion. Under Standing Order No. 9(7), Johnson secured an adjournment debate on 6 November 2017 to mark the 50th anniversary of the Abortion Act $1967 .{ }^{42}$ Creasy successfully sought under Standing Order No. 24 an emergency debate on 5 June 2018 on reforming the law of Northern Ireland in light of the Irish referendum mentioned above. ${ }^{43}$ During those debates, both MPs indicated explicitly that they would shortly seek legislative reform. Neither has yet formally declared a mechanism for achieving reform in this parliamentary session, and any Bill or amendment to an existing Bill is yet to be forthcoming. However the comments made during these debates provide significant insight as to what the two MPs will likely seek to achieve, broadly speaking.

First, it is clear that both Johnson and Creasy would seek to decriminalise abortion by repealing sections 58-59 of the Offences Against the Person Act 1861. This would remove the criminal law element from abortions performed before the 24th week of gestation, and so make section 1(1)(a) of the Abortion Act unnecessary. The effect of this would be a system closer to 'at-will' or 'on-demand' abortion during the first 24 weeks of gestation. However, both Creasy and Johnson have indicated that they would not seek to decriminalise pregnancy after 24 weeks or repeal the Infant Life Preservation Act. ${ }^{44}$ Further, Johnson has suggested that in her intended Bill 'the conditions for accessing abortions post-24 weeks will not change'. ${ }^{45}$ The implication of these statements is that at least sections $1(1)(b)$-(c) on grave or life-threatening risk to the woman, and also presumably section 1(1)(d) on foetal disability, of the 1967 Act would remain in effect.

\footnotetext{
${ }^{39}$ HC Deb 19 April 2017 vol 624 c680.

${ }^{40}$ Brazier and Fox n 21 above, 202. See also HC 684 (2016), para 50.

${ }^{41}$ House of Commons, 'Members Entering for the Ballot for Bills, as at Tuesday 24 May 2016' n 27 above; Parliament, 'News: Private Members' Bill Ballot: 26 May 2016' n 19 above.

42 HC Deb 06 November 2017 vol 630 cols 1302-1310.

${ }^{43}$ HC Deb 05 June 2018 vol 642 cols 89-90, 205-257.

${ }^{44} \mathrm{HC}$ Deb 05 June 2018 vol $642 \mathrm{col} 219$.

${ }^{45}$ HC Deb 06 November 2017 vol 630 col 1305.
} 
This article has been accepted for publication in the Modern Law Review, and is scheduled to appear in (2019) 82:1.

Secondly, both Johnson and Creasy have suggested that the role of medical personnel in the treatment for abortion should be changed. The requirement for two doctors to authorise an abortion appears likely to be removed in any decriminalising Bill. That change to the required medical authorisation, combined with the step towards on-demand abortion, means that any proposed Bill would increase patient autonomy and address criticisms of the current emphasis on medical paternalism thereby. ${ }^{46}$ Despite this, some continued decision-making on legal grounds by the medical profession within the first 24 weeks of pregnancy still seems to be anticipated: for example, gender-selective and coerced abortions would continue to be prohibited, and this would presumably be enforced by the discretion of the medical profession. It does not seem that the MPs would seek to remove the prescription of the pills used in medical abortion from being subject to the Human Medicines Regulations 2012. ${ }^{47}$ Finally, it was also suggested by Johnson that in her intended Bill ' $[\mathrm{h}]$ ]ealthcare professionals who assist in abortions ... will receive further protections after 24 weeks'; ${ }^{48}$ it is not yet clear what is envisaged, or whether this will be relevant to the conscientious objection clause in section 4 of the 1967 Act.

Finally, it seems likely that the MPs would seek to allow for self-administration of the second pharmaceutical to be given in medical abortion, misoprostol, in a woman's own home. This would follow the recent changes to this effect in Scotland and Wales, about which more will be said below.

Given what has been said above about PMBs introduced by the Ten Minute Rule or as Presentation Bills, it is unlikely that any Bill introduced now would be passed in this parliamentary session. Although the current session is double-length, a motion to increase the number of days reserved for PMBs from 13 was rejected on 17 July 2017. The remaining dates at the time of writing are therefore only 6 July, 26 October and 23 November $2018 .{ }^{49}$ It is possible that Johnson and Creasy will continue to use any further debates which might be secured through the Backbench Business Committee to raise awareness and predict arguments likely to be brought against any Bill introduced in a future Parliament. ${ }^{50}$ Indeed, the Abortion Act 1967, introduced as the Medical Termination of Pregnancy Bill, benefited in this regard from the two prior and related Bills introduced to the House of Lords by Lord Silkin. ${ }^{51}$

Alternatively, it is possible that the reforms proposed by Johnson and Creasy will be integrated into another Bill which has a greater chance of being enacted in the current parliamentary session. This was reportedly the circumstances under which the reforms to the law of abortion were introduced into the text of the Human Fertilisation and Embryology Act 1990, which was a Government Bill that received text from a PMB introduced by Lord Houghton. ${ }^{52}$ That such an option might be pursued in the current instance has been suggested by the Chair of the Health Committee, Dr Sarah Wollaston, who noted that 'We know that there is an opportunity to put this right with an amendment to the domestic violence Bill[.] ... We know that a cross-party amendment will be tabled, and now is the time to be planning ahead and making the thoughtful, careful preparations that we need to make about

\footnotetext{
${ }^{46}$ On which, see eg Sheldon, 'British Abortion Law' n 6 above, especially at 291-7; J. Wyatt, 'Medical Paternalism and the Fetus' (2001) 27 Supp 2 Journal of Medical Ethics ii15-ii20; E. Jackson, 'Abortion, Autonomy and Prenatal Diagnosis' (2000) 9 Social and Legal Studies 467-494.

${ }^{47}$ HC Deb 05 June 2018 vol 642 col 226.

${ }^{48}$ HC Deb 06 November 2017 vol 630 col 1305.

${ }^{49}$ HC Deb 17 July 2017 vol 627 cols 651-655.

${ }^{50}$ On the role of the Backbench Business Committee, see House of Commons Standing Order No. 14(3A)-(3D).

${ }^{51}$ On which, see Paintin $\mathrm{n} 1$ above, chs 2-3.

52 ibid ch 8.
} 
This article has been accepted for publication in the Modern Law Review, and is scheduled to appear in (2019) 82:1.

the kind of medical regulations we wish to see in place. ${ }^{53}$ The consultation period for the Domestic Abuse and Violence Bill has concluded, ${ }^{54}$ but the Bill is yet to be introduced to Parliament.

The above critique of recent attempts to change the law of abortion in the House of Commons has highlighted major deficiencies in the PMB procedure, the principal mechanism through which legislative reform to the law of abortion has been sought and achieved to date. However, the drawbacks of the system have not gone unnoticed. There were calls for the procedure to be reformed by the Procedure Committee of the House of Commons during the 2015-16 parliamentary session. These reforms included a lower limit on the number of PMBs to be prioritised, and new mechanisms for identifying these, in order to give those selected a greater chance of being implemented into law; greater rigour would be introduced for Bills introduced under the Ten Minute Rule. However the Committee's proposals were not adopted by the Government. ${ }^{55}$ It remains unclear whether or not these much-needed reforms will ever take place.

\section{LAW REFORM FOR RESTRICTING ACCESS IN THE HOUSE OF LORDS}

Meanwhile, two PMBs to restrict the law of abortion are currently under consideration by the House of Lords. The rules for introducing a PMB in the House of Lords differ from those of the House of Commons. Although priority is similarly given to Government Bills in the Lords, there is, unlike in the Commons, no formal cap on the number of days when PMBs can be introduced and debated, nor are there any other time limits for those allotted days. ${ }^{56}$ As Brazier and Fox note, 'peers have an unrestricted right to introduce PMBs'. ${ }^{57}$ In practice, however, the right of a peer to introduce a PMB and have it debated on the floor of the House is subject to certain customs and traditions. For example, 'Debates on private member's bills in the Lords usually take place on a Friday ... the House of Lords usually has around ten sitting Fridays each session, and often considers three or four private member's bills during a Friday sitting. ${ }^{58}$

Since the 2015-16 parliamentary session, following the recommendation of the House of Lords Procedural Committee ${ }^{59}$ approved by the House of Lords, ${ }^{60}$ a ballot has also been held in order to determine the order in which PMBs in the House of Lords are to receive their first reading. In order to participate in the ballot, a peer must submit the text of the proposed Bill before the rise of Parliament on the day of the State Opening, with the ballot taking place the following day. ${ }^{61}$ This is in stark contrast to the ballot in the Commons, where an MP need not even have a Bill in mind, yet alone a draft text, in order to participate. Where a PMB successfully passes each legislative stage of the Lords, it may only proceed to the Commons for consideration if it is supported by an MP, and even so is not

\footnotetext{
53 HC Deb 05 June 2018 vol 642 col 226.

${ }^{54}$ HM Government, 'Transforming the Response to Domestic Abuse: Government Consultation' (2018); Impact Assessment MoJ016/2017, HO0300. Both available at https://consult.justice.gov.uk/homeoffice-moj/domestic-abuse-consultation/.

55 HC 684 (2016); HC 701 (2016); HC 937 (2017).

${ }^{56}$ House of Lords, Companion to the Standing Orders and Guide to the Proceedings of the House of Lords (25th edn, 2017), 107-108, para 8.30.

${ }^{57}$ Brazier and Fox $\mathrm{n} 21$ above, 202.

58 Library Briefing $\mathrm{n} 16$ above, para.6.2.

${ }^{59}$ House of Lords procedure Committee, Private Members' Bills, Topical Questions for Short debate: Select Committee Reports, 10 December 2013, HL Paper 63 of session 2013-14, pp.3-4. Available here: https://publications.parliament.uk/pa/ld201314/Idselect/ldproced/63/63.pdf.

${ }^{60}$ HL Deb 09 January 2014 vol 750 col 1629.

${ }^{61}$ Companion to the Standing Orders n 54 above, 104 para 8.13.
} 
This article has been accepted for publication in the Modern Law Review, and is scheduled to appear in (2019) 82:1.

accorded priority over any other Bill in the House of Commons. This is in stark contrast to the Commons, where a successful PMB is likely to be accorded sufficient time in the House of Lords for consideration when it moves there.

\section{The Abortion (Disability Equality) Bills 2016-17 and 2017-19}

The Abortion (Disability Equality) Bill was introduced by Lord Shinkwin first in the 2016-17 parliamentary session, receiving the 12th slot in the ballot. ${ }^{62}$ It was introduced on 25 May 2016 as one of five Bills given their first reading in under two minutes. ${ }^{63}$ Lord Shinkwin conveyed the purpose of the Bill at its second reading as being to address 'an inconsistency in the law, whereby discrimination on grounds of disability is both prohibited in law after birth yet, confusingly, actually enshrined in law at the very point at which the discrimination begins, at source, before birth. ${ }^{64}$ The Bill was described by Lord Shinkwin as being one of disability rights rather than abortion. However, it is inescapable that the Bill, if enacted, would restrict the availability of abortion, and as a result will be considered by this article in those terms. The Bill progressed only to the report stage before the end of the parliamentary session. ${ }^{65}$ Lord Shinkwin sought again to introduce a Bill by this same name in the 2017-19 ballot, in which he was allocated the 51st slot; his Bill was accordingly introduced on 11 July 2017. ${ }^{66}$ Despite having the same name, the Bill has slightly differing text to the version introduced in the previous Parliament.

Section one of the first Bill (both as introduced and having passed committee stage) sought to prohibit abortion or procuring a miscarriage on the ground of foetal disability. The mechanism for making that change in law was the repealing of sections 1(1)(d) and 5(2)(a) of the Abortion Act 1967, and making some minor, consequential changes to the wording of section $5(2)(b)$.

When re-introduced in the present parliamentary session, the Bill's repeal of section $5(2)(a)$ and revision of section $5(2)(b)$ were unchanged. However, section $1(1)$ (d) would no longer be repealed, but rather time-bound to 24 weeks. This different approach might reflect the discussion during the report stage of the previous Bill, which repeatedly returned to the difference between abortions performed under section $1(1)$ (d) before and after this term of gestation. ${ }^{67} \mathrm{~A}$ new section would also be added to the 1967 Act, as section 1(2A), which would require the parents (not only the pregnant individual) to be provided with information on 'all options following a prenatal diagnosis of disability, including the keeping of that child'. This information would include information supplied by 'disability family support groups and organisations led and controlled by disabled persons.'

The use of section $1(1)(d)$ has proven to be controversial in the past. ${ }^{68}$ In support of his Bill, Lord Shinkwin added to the existing controversy around abortions for specific foetal abnormalities. The particular example he raised was the abortion of foetuses with cleft palates, which he deemed 'an

\footnotetext{
62 Parliament, 'News: House of Lords Private Members' Bill Ballot: 2016-17' at https://www.parliament.uk/business/news/2016/may/house-of-lords-private-members-bill-ballot-2016-171/. ${ }^{63} \mathrm{HL}$ Deb 25 May 2016 vol 773 [sic].

${ }^{64} \mathrm{HL}$ Deb 21 October 2016 vol 774 col 2545.

${ }^{65}$ HL Deb 21 October 2016 vol 774 cols 2544-2562 (second reading); HL Deb 27 January 2017 vol 778 cols 885891 (committee); HL Deb 24 February 2017 vol 779 cols 546-564 (report).

66 Parliament, 'News: House of Lords Private Members' Bill Ballot Results 2017' at https://www.parliament.uk/business/news/2017/june/house-of-lords-private-members-bills-ballot-results2017/.

67 HL Deb 24 February 2017 vol 779 cols 546-564.

${ }^{68}$ For an earlier discussion, see e.g. Jackson $\mathrm{n} 44$ above, 479-84; S. McGuiness, 'Law, Reproduction, and Disability: Fatally “Handicapped”?' (2013) 21 Medical Law Review 213-242.
} 
This article has been accepted for publication in the Modern Law Review, and is scheduled to appear in (2019) 82:1.

easily surgically rectifiable condition' ${ }^{69}$ The example of cleft palates has been debated in Parliament previously. ${ }^{70}$ An instance of abortion for this condition was also raised in Jepson $v$ Chief Constable of West Mercia [2003] EWHC 3318 (QB). Jepson, a Church of England curate, had received permission to judicially review the decision not to prosecute doctors who had aborted such a foetus at 'more than 24 weeks [sic] gestation'. However, the case was not progressed further. ${ }^{71}$

At the second reading of the Bill, Lord Shinkwin also used statistics which he suggested showed a significant increase in the number of abortions on this ground in recent decades. According to Lord Shinkwin, 'There were 230 terminations after 24 weeks on grounds of disability in 2015, and a 56 per cent increase in the number of terminations on grounds of disability after 24 weeks over the last five years, between 2010 and 2015. ${ }^{72}$ The statistical evidence for a longer 10-year period does indeed show that the overall trend for abortion on the basis of section 1(1)(d) has increased. There were ca. 2000 such abortions per annum in 2008 and 2009, rising to and then largely plateauing at ca.3200 in 2015 to $2017 .{ }^{73}$ The number of abortions performed under section 1(1)(d) after 24 weeks was 124 in 2008, usually increasing year-on-year to reach ca.230 in 2015 to 2017. The proportion of abortions carried out after 24 weeks relative to all those conducted on the basis of section 1(1)(d) was constant at circa six to six-and-a-half per cent in 2008 to 2012, then increased to circa seven per cent in most of the years since. The incidences of section $1(1)$ (d) abortions has therefore increased over the last 10 years. It has, however, been approximately constant, and has ceased to rise, in the last three years. It is therefore unclear whether the future trend will be for an increase in these numbers or not.

This combination of evidence has been presented to Parliament to convince the Lords that section $1(1)$ (d) should be repealed. Yet, there are counter-arguments against repealing or time-limiting section $1(1)$ (d). First, the rate of abortions performed under this sub-section after 24 weeks of gestation is now typical of rates across much of Europe, which approximate seven per cent. ${ }^{74}$ Therefore the frequency of use of section $1(1)(d)$ is not unusual.

Secondly, as was indicated in the House of Lords by the professor and surgeon Lord Winston, correctable conditions such as cleft palate can be indicators of more serious foetal abnormalities; ${ }^{75}$ the RCOG confirms that this is the case in 30 per cent of those born with a cleft palate; ${ }^{76}$ another study suggested that around two-thirds of those born with cleft-palate had additional 'major malformations' ${ }^{77}$ Each of the abortions included in the statistical evidence mentioned above would

\footnotetext{
69 HL Deb 21 October 2016 vol 774 col 2547.

70 See eg HL Deb 16 March 2004 vol 659 cols 215-230.

${ }^{71}$ On which, see eg A. Grear, 'The Curate, a Cleft Palate and Ideological Closure in the Abortion Act 1967-Time to Reconsider the Relationship between Doctors and the Abortion Decision' (2004) 4 Web Journal of Current Legal Issues.

72 HL Deb 21 October 2016 vol 774 col 2547.

73 Department of Health, 'Abortion Statistics, England and Wales: 2016' (2017 rev. January 2018), 34; Department of Health, 'Abortion Statistics, England and Wales: 2015' (2016), 31.

${ }^{74}$ E. Garne et al, 'Termination of Pregnancy for Fetal Anomaly after 23 Weeks of Gestation: A European Register-Based Study' (2010) 117 British Journal of Obstetrics and Gynaecology 660-666, 661.

75 HL Deb 24 February 2017 vol 779 col 563. For further discussion of remediality and section 1(1)(d), see R. Scott, 'Interpreting the Disability Ground of the Abortion Act' (2005) 64 Cambridge Law Journal 388-412, esp. 393-5.

${ }^{76}$ Royal College of Obstetricians and Gynaecologists, 'Human Fertilisation and Embryology Bill Q\&A: Abortions for Fetal Abnormality' (July 2008), at https://www.rcog.org.uk/en/news/campaigns-and-opinions/human-fertilisation-and-embryology-bill/qaabortions-for-fetal-abnormality/.

77 A. A. Mueller et al, 'Central Nervous Malformations in Presence of Clefts Reflect Developmental Interplay' (2007) 36 International Journal of Oral and Maxillofacial Surgery 289-295.
} 
This article has been accepted for publication in the Modern Law Review, and is scheduled to appear in (2019) 82:1.

have had two doctors opine that (according to the section) 'there is a substantial risk that if the child were born it would suffer from such physical or mental abnormalities as to be seriously handicapped'. If the two doctors had not believed in good faith that the abnormalities (including those of cleft palate) were sufficiently serious to meet the test under section $1(1)(d)$, then those abortions would already have been unlawful.

Thirdly, as Lord Winston also noted, the increasing proportion of abortions on this ground performed after 24 weeks of gestation might be explained by doctors advising parents to wait to see how a condition developed before making the decision as to whether to abort. The RCOG has also explained that the second prenatal scan will normally take place at 18-20 weeks of gestation, with a third scan offered at around 22 weeks if an abnormality is thought likely. In the Bill were enacted, therefore, a pregnant woman would be required to make a decision as to whether to continue with the pregnancy very quickly, and would perhaps be unable to wait for further tests to be conducted or receive any sustained counselling. Finally, some serious foetal abnormalities will become apparent or detectable by ultrasound only after 24 weeks. ${ }^{78}$

The repeal of section $1(1)(d)$ would have a considerable impact. The change to the Bill's text to continue to allow abortions under section $1(1)$ (d) before the 24th week of gestation may make little difference in practice from simply repealing it entirely, given the mental or physical health of the woman under section 1(1)(a) already provides alternative grounds during these weeks. It is therefore submitted that significant and objective consultation should be undertaken on the wider medical situation before any such legislative amendment be considered. This is necessary in order to contextualise the issue of abortion for conditions such as cleft palate, the statistical evidence, and other considerations.

The second clause of the 2016-17 Bill as passed in committee would have compelled the Secretary of State to consider the impact of the new legislation on 'disabled children, their families and carers, and the provision of support services' and to report on such matters to both Houses of Parliament. This clause was introduced to the Bill as an amendment at the committee stage. It has not been included in the Bill introduced in the current parliamentary session.

Finally, clause 3 determined the 2016-17 Bill's extent, commencement and short title. Clause 3(1) as introduced and passed at committee declared the Bill's extent to include England, Wales and Scotland. ${ }^{79}$ The extension of the Bill to Scotland would have been constitutionally contentious: the devolution to the Scottish Parliament of competency over abortion, which will be discussed below, had taken effect two days before Lord Shinkwin's Bill was introduced. However, Scotland's inclusion within the Bill's extent was likely an attempt to amend the Abortion Act 1967 as it then applied rather than one to encroach upon the new competencies of Holyrood. Indeed, Lord Shinkwin co-sponsored an amendment to remove the reference to Scotland at the report stage. It is notable, given the pressures with regard to Northern Ireland mentioned previously and discussed in more detail below,

\footnotetext{
${ }^{78}$ Lyn Bryant, Adam Fisher \& Fiona Vicente, 'Fetal Anomaly Ultrasound Screening Programme Study: Literature Survey' (Plymouth: Plymouth Social Research \& Regeneration Unit, 2007), at http://www.serio.ac.uk/resources/files/NHS\%20Fetal\%20Anomaly\%20Ultrasound\%20Screening\%20Programm e\%20Study\%20.pdf.

79 The Bill's text as amended at Committee can be accessed at https://publications.parliament.uk/pa/bills//bill/2016-2017/0095/17095.pdf.
} 
This article has been accepted for publication in the Modern Law Review, and is scheduled to appear in (2019) 82:1.

that Lord Winston meanwhile proposed an amendment to add that constituent nation to the extent of the Bill. ${ }^{80}$

Only one day of the report stage took place before the end of the parliamentary session, on which only the amendments to the first clause of the Bill were directly examined.$^{81} \mathrm{Had}$ Lord Shinkwin's Bill extended to either Scotland, Northern Ireland or both nations, the Sewel Convention stipulates that the Westminster Parliament, when legislating on a devolved matter, will not normally do so without the consent of the devolved legislatures. ${ }^{82}$ Given the contentious nature of the proposed Bill, it seems unlikely that devolved consent would not have been sought had the Bill progressed further. The extent has been reduced in the current Bill to England and Wales.

\section{The Abortion (Foetus Protection) Bill 2017-19}

Another Bill to restrict the law of abortion has also been introduced in the House of Lords in the present Parliament. Baroness Nicholson of Winterbourne entered into the ballot the new Abortion (Foetus Protection) Bill 2017-19, and was allocated the 34th slot; the Bill was therefore introduced on 5 July 2017. This new Bill proposes to reduce the gestation deadline for abortions under section 1(1)(a) of the 1967 Act from 24 to 12 weeks in England and Wales. The Bill now awaits its second reading, the date of which was yet to be announced at the time of writing.

It is submitted that the impact of the Bill, if enacted, or any like reforms proposed in the future, would be significant. As such, at its second reading the potential impact of the Bill on the physical and mental health of women in England and Wales should be clear to those involved. Section 1(1)(a) was the basis for 12,834 abortions performed for residents of England or Wales during or after the 13th week of gestation in 2016. This was a marginal increase on 2015, in which there were 12,642 such abortions. ${ }^{83}$ This means that the option of abortion would be removed by this Bill from approximately 12,500 women in England and Wales each year. These women would thus have to continue a pregnancy which represented, in the wording of the Act, a 'risk, greater than if the pregnancy were terminated, of injury to the physical or mental health of the pregnant woman or any existing children of her family'.

The lack of discussion of the new Bill on its introduction to Parliament means there was no acknowledgement of its underlying rationale. However, some insight can be had from the earlier parliamentary record. The Baroness spoke for eight minutes in favour of Lord Shinkwin's Bill at its second reading. ${ }^{84}$ She began by lauding the Bill's 'step forward in logical thinking and in the investigation of what we as a society feel about handicap' ${ }^{85}$ Most of her speech focused on disability rights and the inconsistency of section 1(1)(d) of the 1967 Act with the current understanding of these rights. It is submitted that other aspects of her speech provide an insight into the motivation and rationale for the subsequent introduction of her own Bill: her opposition to abortion more generally, or at least that she would favour more restrictive abortion laws. First, she termed abortion 'a form of capital punishment'. ${ }^{86}$ Secondly, she made a comparative reference to Germany, where she said 'a would-be mother, a pregnant lady, can have an abortion at any time up to 12 weeks, with nothing

\footnotetext{
${ }^{80}$ Both amendments' texts as moved at report can be accessed on the marshalled list of amendments at https://publications.parliament.uk/pa/bills/lbill/2016-2017/0095/17095-I.pdf.

${ }^{81}$ HL Deb 24 February 2017 vol 779 cols 546-564.

82 Scotland Act 1998, s 28(8).

${ }^{83}$ As calculated from the data in 'Abortion Statistics, England and Wales: 2016' n 71 above, 34; 'Abortion Statistics, England and Wales: 2015' n 71 above, 31.

${ }^{84}$ HL Deb 21 October 2016 vol 774 cols 2550-2552.

${ }^{85}$ HL Deb 21 October 2016 vol 774 col 2550.

${ }^{86}$ HL Deb 21 October 2016 vol 774 col 2550.
} 
This article has been accepted for publication in the Modern Law Review, and is scheduled to appear in (2019) 82:1.

except a consultation with a medical professional and three days' waiting time-but after 12 weeks nothing is allowed, unless the health of the mother is severely compromised. ${ }^{87}$ It is perhaps unsurprising, therefore, that her own Bill goes considerably further than Shinkwin's in terms of restricting access to abortion. At the same time, it is notable that, in leaving the other provisions of the 1967 Act unchanged, the Bill fails to offer the same disability protections she had lauded previously.

A detailed comparative legal analysis of abortion in Germany is beyond the scope of this article. It can be said, however, that the Baroness' comparison with Germany is both misleading and contradictory. Although section 218 of the German Criminal Code makes abortion an offence, section 218a(1) nevertheless excludes from the offence those terminations that are undertaken by a physician, where the pregnancy has not progressed more than 12 weeks, and where the pregnant woman can demonstrate that she received counselling three days prior to the abortion. The Baroness appears to use German law as evidence for reducing the termination period from a notional 24 weeks to 12 , as well as removing abortion on the basis of foetal abnormality. However the comparator is complex. Despite the role of counselling being to protect the life of the foetus, it is nevertheless the decision of the woman-and under a strict reading of the Code it seems only the woman-as to whether to abort the pregnancy or not. This permits greater patient autonomy than in the UK, even though the timeframe is half that permitted under the Abortion Act. Furthermore, aspects of the German law of abortion is currently under pressure to reform..$^{88}$

It is submitted that the Baroness' comparison to German law highlights the dangers of using the law of other jurisdictions on this issue as evidence for legal reform, wherever that comparator may be on the scale of permissive to restrictive abortion law. At least, any comparison made should be presented objectively and fully. Crucially, however, there is no consensus amongst other Western legal systems on the issue, with a broad range of legal positions being both adopted and not always adhered to in practice. ${ }^{89}$ Furthermore, such variation is in large part due to the unique political circumstances of each nation, including Germany, ${ }^{90}$ thus making any singular comparisons inadvisable. The devolved nature of the law in the UK adds an additional layer of complexity to any comparative modelling due to the variations in both law and practice exhibited amongst the constituent nations.

\section{THE DEVOLUTIONARY SETTLEMENTS, LAW REFORM AND EXERCISE OF MINISTERIAL FUNCTION}

This article has thus far examined the activities at Westminster relevant to the reform of the law of abortion with respect, largely, to English law. The focus of Westminster on English law specifically is explained by the previous devolving of competence in the law of abortion to the Assemblies of Northern Ireland and Wales and the Parliament of Scotland. The devolving of competence in this area to these three legislative bodies has been done at different times, using different mechanisms, and to

\footnotetext{
${ }^{87}$ HL Deb 21 October 2016 vol 774 col 2551.

88 Deutscher Bundestag, 'Recht und Verbraucherschutz: Mittwoch, 27. Juni 2018, 18.30 Uhr - § 219a StGB' (2018); Gesetzentwurf, BT-Drucksache 19/93, 19/820, 19/630.

89 For example, Canada's legal system has had no enforceable restriction on abortion since the relevant provisions in the Criminal Code were struck down in $R v$ Morgentaler [1988] 1 SCR 30. This this has led to regional discrepancy in provision, on which see. Johnstone, After Morgentaler: The Politics of Abortion in Canada (Vancouver: University of British Columbia Press, 2017).

${ }^{90}$ Y. Frankfurth, 'Mothers, Morality and Abortion: The Politics of Reproduction in the Formation of the German Nation' (2017) 18 Journal of International Women's Studies 51-65; D. A. J. Telman, 'Abortion and Women's Legal Personhood in Germany: A Contribution to the Feminist Theory of the State' (1998) 24 New York University Review of Law \& Social Change 91-148.
} 
This article has been accepted for publication in the Modern Law Review, and is scheduled to appear in (2019) 82:1.

varying extents and degrees of clarity. This article will examine the devolutionary process with respect to these three nations, and the current issues of abortion law reform connected to this, in turn.

\section{Northern Ireland}

\section{Abortion and the Northern Irish devolutionary settlement}

Northern Ireland's devolutionary settlement uses a tripartite classification system to distinguish areas of law within the competency of the Assembly at Stormont. So-called 'transferred' matters are those given into the competence of Northern Ireland. 'Reserved' matters are those which are yet to be given into that competence but which could be transferred by the Secretary of State at a later date and on which, in the meantime, Stormont could pass legislation with the consent of the Secretary of State under section 8 of the Act. 'Excepted' matters are those which are kept to Westminster and cannot be transferred without further primary legislation. ${ }^{91}$

The law of abortion has not been devolved as a distinct area of law. The understanding that abortion has been transferred is based on its inclusion within the remit of the criminal law. Specifically, abortion is an offence under sections 58-59 of the Offences Against the Person Act 1861 and sections 25-26 of the Criminal Justice Act (Northern Ireland) 1945, and is lawful only where the pregnancy is a threat to the life of the mother or her mental or physical health is severely compromised. ${ }^{92}$ The application of these Acts without the exemptions of the Abortion Act 1967 means that Northern Ireland has the most restrictive abortion laws in the UK.

The criminal law was originally a reserved matter under schedule 3, article 9(a) of the Northern Ireland Act 1998. It later became a transferred matter, and so within the legislative discretion of Stormont, by the Northern Ireland Act 1998 (Amendment of Schedule 3) Order 2010.

Westminster considered whether the definition of 'criminal law' should include abortion during the passage of the 1998 Act. This was confirmed to be the case in the House of Commons by the Secretary of State, Marjorie Mowlam, and the House of Lords by the Parliamentary Under-Secretary for the Northern Ireland Office, Lord Dubs. ${ }^{93}$ However, the identification of abortion as a reserved matter rather than a transferred matter was controversial in the House of Lords. An amendment was moved, debated and withdrawn by Lord Molyneaux of Killead at committee, then moved again at the report stage, to add after the listing of the criminal law as a reserved matter the phrase "but not the law relating to abortion'.$^{94}$ The effect of such an amendment would be to transfer competence in this area of law to Stormont immediately. Ultimately, the amendment was narrowly defeated, at 104 for and

\footnotetext{
${ }^{91}$ On these distinctions, see B. Hadfield, 'The Nature of Devolution in Scotland and Northern Ireland: Key Issues of Responsibility and Control' (1999) 3 Edinburgh Law Review 3-31 at 16-18.

92 Re K (unreported) October 1993, following $R$ v Bourne [1939] 1 KB 687; Northern Health and Social Services Board $v$ AMNH etc. (unreported) January 1994; both cited in T. McGleenan, 'Bourne again? Abortion law in Northern Ireland after Re K and Re A' (1994) 45 Northern Ireland Legal Quarterly 389-394. Additionally, on a previous unsuccessful attempt to bring clarity to the law, see B. Hewson, 'The Law of Abortion in Northern Ireland' [2004] Public Law 234-245; E. V. Fegan and R. Rebouche, 'Northern Ireland's Abortion Law: The Morality of Silence and the Censure of Agency' (2003) 11 Feminist Legal Studies 221-254.

${ }^{93}$ HC Deb 20 July 1998 vol 316 cols 815-816; HL Deb 05 October 1998 vol 593 col 228. On debate in the House of Commons at this time, as well as analysis of other debates before and after devolution, see J. Thomson, 'Explaining Gender Equality Difference in a Devolved System: The Case of Abortion Law in Northern Ireland' (2016) 11 British Politics 371-388.

${ }^{94}$ HL Deb 27 October 1998 vol 593 cols 1861-1869.
} 
This article has been accepted for publication in the Modern Law Review, and is scheduled to appear in (2019) 82:1.

160 against. ${ }^{95}$ However, it is worth examining briefly two issues raised during the debates on this amendment with respect to the devolution settlements.

First, the House of Lords were highly conscious that the devolutionary settlements were inconsistent on this issue: abortion was proposed as a reserved matter for Northern Ireland (and so within the competence of Stormont where the Secretary of State consented), but kept to Westminster expressly in the case of Scotland. ${ }^{96}$ Lord Dubs put forward the case on behalf of the Government that the Northern Irish settlement had to adhere to the Good Friday Agreement (which classified criminal law as a reserved matter). There was also acknowledgement from members that the land border between Scotland and England in the first case and between Northern Ireland and the Republic of Ireland in the second meant that a greater consistency between those two pairs of adjacent legal systems was desirable.

Secondly, clear assurances were given by Lord Dubs that, although abortion would be a reserved matter, 'any change at all in the law relating to abortion would need the most careful consultation in Northern Ireland. We have no wish to foist anything on the people there that is against their will. I think that that is a clear statement' ${ }^{\prime 97}$ However, other members suggested that Westminster should retain competence, either to homogenise the law across the UK, or because abortion was 'one of those fields where local majority opinion should not necessarily prevail over minority rights, and it may be that in the future-not immediately-the Westminster Parliament will decide that certain minimum rights in this sphere should prevail throughout the United Kingdom. ${ }^{98}$ These same debates have had new relevance in recent months.

\section{Calls to reform Northern Irish law in Westminster}

The devolving of abortion law means that it would be expected that any desired legislative reform would be introduced only at Stormont. However, calls have recently been made in Westminster to intervene. Westminster retains the ability to legislate for this matter in Northern Ireland as the UK's sovereign parliament and by express provision under section 5 of the Northern Ireland Act 1998, ${ }^{99}$ and a functioning Northern Irish Government has been lacking for 18 months at the time of writing. The Conservative Prime Minister, Theresa May, has thus been called on to legislate for Northern Ireland. This is not the first time since devolution that such calls have been made, ${ }^{100}$ and indeed the extension of abortion rights in Northern Ireland was a manifesto commitment of the Labour Party in the 2017 General Election. ${ }^{101}$ However, a new impetus is found in the referendum in the neighbouring Republic of Ireland in May 2018, which has resulted in renewed attention within the UK on the similarly restrictive laws in Northern Ireland. Hence the aforementioned House of Commons debate in June 2018, in which Stella Creasy promised forthcoming legislation on abortion law, was enabled by an emergency motion to address the position of Northern Ireland in light of that referendum.

\footnotetext{
${ }^{95}$ HL Deb 11 November 1998 vol 594 cols 792-803.

96 The House of Commons also noted this inconsistency, but with a focus on the Scottish side. On which, see Thomson $\mathrm{n} 91$ above, 379-380.

${ }^{97}$ HL Deb 27 October 1998 vol 593 col 1868.

${ }^{98}$ HL Deb 11 November 1998 vol 594 col 796, per Lord Monson.

99 On which, see Hadfield n 89 above, 23-25.

100 On a previous call for Westminster to reform Northern Ireland's laws after devolution, see Thomson n 91 above, 371-388.

101 Labour party, 'For the Many, Not the Few', 109, at https://labour.org.uk/wpcontent/uploads/2017/10/labour-manifesto-2017.pdf.
} 
This article has been accepted for publication in the Modern Law Review, and is scheduled to appear in (2019) 82:1.

The Westminster Government is in a difficult position politically in regard to the calls for it to reform the law in Northern Ireland. The Conservative majority was lost in the 2017 General Election, and a confidence and supply agreement was entered into with the Democratic and Unionist Party (DUP) of Northern Ireland to ensure a working majority on key votes. Critics of the agreement condemned the DUP's socially conservative stance on abortion. ${ }^{102}$ Since the referendum, members of the DUP have warned that any move to reform abortion law in Northern Ireland would threaten their support for the Conservative Government in the upcoming Brexit votes. ${ }^{103}$ Any reform by Westminster could therefore have considerable political importance beyond the law of abortion itself.

The Conservative Government has previously faced political difficulties arising from the law of abortion. On 14 June 2017, the Supreme Court held that the levying of fees on Northern Irish women who sought abortions in England was lawful. ${ }^{104}$ Stella Creasy accordingly proposed an amendment to the Queen's speech, the text of which was at that time being negotiated. Her amendment would 'ensure the provision of adequate funding and guidance so that all UK citizens including those from Northern Ireland may access medical services including abortion procedures in England if they so wish without charge'. ${ }^{105}$ That amendment was selected by the Speaker of the House of Commons on the morning of 29 June 2017. Speculation followed that the amendment would pass and thereby cause embarrassment to the Conservative-DUP alliance. By mid-afternoon, the Women and Equalities Minister, Justine Greening, confirmed that her budget would pay for the abortion treatments of Northern Irish women. ${ }^{106}$ Stella Creasy withdrew her amendment accordingly, allowing the Queen's speech to pass without amendment.

\section{Proposed Reform at Stormont}

These debates (and indeed the legal literature ${ }^{107}$ ) have overlooked the fact that, prior to the decision of the Members of the Legislative Assembly (MLAs) not to meet, Stormont has not passively received devolved authority in this area of law but has already started exercising these powers. Indeed, Stormont was considering a Bill on abortion before it stopped sitting in January 2017. The Alliance MLA David Ford had in December 2016 introduced the Abortion (Fatal Foetal Abnormality) Bill to Stormont, whereupon it passed its first reading. ${ }^{108}$ The Bill fell when the Assembly was dissolved the following month, but remains important because it was only the most recent attempt to introduce the provisions therein. It is likely that the Bill's text, or at least its legislative purpose, will be re-

\footnotetext{
102 The Guardian, 'Never Mind the SNP. The Real Danger is if the DUP are in Government' (24 April 2015); The Huffington Post, 'DUP's Record On Abortion, Creationism and LGBT Rights. Oh my...' (9 June 2017).

${ }^{103}$ Sky News, 'DUP Warns of “Consequences” over Northern Ireland Abortion Calls' (29 May 2018).

${ }^{104} R$ (on the application of $A$ and B) (Appellants) $v$ Secretary of State for Health (Respondent) [2017] 1 W.L.R. 2492; [2017] 4 All E.R. 353. On which, see eg S. Cragg, 'Abortion, Northern Ireland and the NHS in England: Can Respect for Devolved Governments Be a Justification for Discrimination' (2017) 4 Journal of International and Comparative Law 377-388.

${ }^{105}$ HC OP 2 (26 June 2017), part 1, 5-6.

$106 \mathrm{~J}$. Greening, Letter to the Members of the House of Commons (26 June 2017), accessed at https://assets.publishing.service.gov.uk/government/uploads/system/uploads/attachment_data/file/623669/ Letter_from_Justine_Greening_on_Abortion_in_England.pdf

107 See eg C. Pierson, 'One Step Forwards, Two Steps Back: Women's Rights 20 Years after the Good Friday Agreement' (2018) 71 Parliamentary Affairs 461-81, 473-474; C. O'Rourke, 'Advocating Abortion Rights in Northern Ireland: Local and Global Tensions' (2016) 25 Social and Legal Studies 716-740. However, see the inclusion of the debate in February 2016 in a study of the rise and effectiveness on rights language in C. Pierson and F. Bloomer, 'Macro- and Micro-Political Vernaculizations of Rights: Human Rights and Abortion Discourses in Northern Ireland' (2017) 19 Health and Human Rights Journal 173-186.

${ }^{108}$ NI Ass Deb 6 December 2016 vol 118 no 2 p 2.
} 
This article has been accepted for publication in the Modern Law Review, and is scheduled to appear in (2019) 82:1.

introduced in the future. It is therefore important to understand the Bill's proposed legislative changes.

The Assembly's Standing Order No. 30 regulates the introduction of Executive and Non-Executive Bills. Standing Order No. 30(1) requires that any Bill introduced to Stormont must have a text seven working days prior to introduction. Standing Order No. 30(2) requires that any PMB introduced must be accompanied by a declaration of parliamentary competence. Although not specified by the Standing Orders, it is also required that a Bill be accompanied by explanatory notes, and that PMBs undertake a period of consultation (unless allowed an exemption, such as on the basis of prior consultation). ${ }^{109}$ Akin to Presentation Bills at Westminster, Standing Order No. 30(5) states that the introduction of a Bill at Stormont will comprise the reading of the title without debate.

The Abortion (Fatal Foetal Abnormality) Bill as introduced comprised four clauses. ${ }^{110}$ Clause $1(1)$ would allow abortions where 'two suitably qualified registered medical practitioners' believe in good faith that either the foetus will die before or during birth, or that, if born, the life of the foetus could not be saved despite medical intervention, and the abortion is performed by 'a registered medical practitioner'. A 'suitably qualified registered medical practitioner' is defined by clause 1(2) as 'a registered medical practitioner who has achieved a Certificate of Completion of Training to practise in the fields of obstetrics, foetal medicine, gynaecology or paediatrics.' Clause 2 would require women carrying a foetus which meets the test for abortion to be provided with a health assessment, information on her options, opportunity for decision-making, and appropriate care whatever that decision may be. Clause 3 would allow medical practitioners to refuse to participate in abortion treatments because of conscientious objection. Clause 4 included the Bill's proposed commencement and short title.

Even had the Assembly not dissolved in January 2017, it is not clear how far the Bill would have progressed. The Bill's text is almost identical to that of a clause moved by the Alliance MLAs Stewart Dickson and Trevor Lunn as amendment No. 61 to the Justice (No. 2) Bill at Consideration Stage in February 2016. Another amendment (No. 68) discussed at the same time proposed to allow abortion where the pregnancy was a result of 'rape, incest or indecent assault'. ${ }^{111}$ Both amendments were defeated, the former at 40 for to 59 against and the latter at 32 for to 64 against.

Unlike at Westminster, where MPs are allowed to vote by their individual conscience in such matters, many of the MLAs in February 2016 voted according to their party's policy on abortion. The DUP, Social Democratic and Labour Party (SDLP), and Traditional Unionist Voice have policies resisting any reform of the law in this area. Meanwhile, Sinn Féin and the Green Party supported the change. The Ulster Unionist Party and Alliance Party allowed a conscience vote, but all of the former party's MLAs voted against the amendment and all of the latter party's MLAs voted in favour of it.

The DUP at the time of the amendment vote was the party with the most seats in the Assembly. One criticism which contributed to the party's voting decision was that the proposed provisions were

\footnotetext{
${ }^{109}$ NI Assembly, 'About Non-Executive Bills', at http://www.niassembly.gov.uk/assembly-business/legislation/2011-2016-mandate/current-non-executive-billproposals/about-non-executive-bills/. 110 The Bill (No. 03/16-21) as introduced can be found at http://www.niassembly.gov.uk/globalassets/documents/legislation/bills/non-executive-bills/session-20162017/abortion-ffa/abortion-ffa-bill---as-introduced-6.12.16.pdf.

${ }^{111} \mathrm{NI}$ Ass Deb 10 February 2016 vol 112 no 5 pp 77-122.
} 
This article has been accepted for publication in the Modern Law Review, and is scheduled to appear in (2019) 82:1.

presented to the Assembly as an amendment. As the DUP MLA, Emma Little-Pengelly stated in that debate:

It is wrong that an issue of such gravity should be pulled together and thrust on Northern Ireland by way of a last-minute amendment, stapled awkwardly onto a miscellaneous Bill. ... That is why the DUP is rejecting the amendment but outlining a road map to a sensible, informed and appropriate way forward. The Minister of Health has been asked to establish, by the end of February, a working group that will include clinicians in this field and legally qualified persons to make recommendations on how this issue can be addressed, including, if necessary, bringing forward draft legislation. ${ }^{112}$

Members of the SDLP raised similar concern that the change being made by an amendment did not allow MLAs time to consider the issue properly. ${ }^{113}$ This position was met with complaint that the commission sought was a delaying tactic. ${ }^{114}$

The Working Group on Fatal Fetal [sic] Abnormality thus established reported in October 2016, although its report was not published until April 2018. ${ }^{115}$ That report advocated reform to allow for abortion on those grounds. The Bill introduced by Ford would have addressed the concerns of the Working Group and, as a separate piece of legislation, would also have addressed the specific concern of the time allowed for debate. The explanatory note accompanying the new Bill emphasised that the previous commission or Working Group 'received a major response', ${ }^{116}$ implying that a renewed commission was unnecessary.

If party whips continue to ensure adherence to party lines in voting on any future abortion Bill, then reform at Stormont seems unlikely. However, the SDLP decided in May 2018 to allow a conscience vote, and other parties may also do so in due course. ${ }^{117}$ It is possible (but not clear) that, if allowed to vote by their individual conscience, there would be sufficient MLAs to pass any future Bill along the lines of the Abortion (Fatal Foetal Abnormality) Bill. Some suggestion of this might be found in that one DUP and one SDLP MLA voted both for and against amendment 61, which (as at Westminster) is a form of abstention by cancelling out one's vote.

\section{Scotland and Wales}

Holyrood received parliamentary legislative competence in abortion law after the 2014 Scottish independence referendum. The Smith Commission established after that referendum opaquely suggested that abortion law might be considered for devolution. ${ }^{118}$ The Scotland Bill as originally proposed did not include such a provision, but the Secretary of State for Scotland indicated his support for an amendment. ${ }^{119}$ Thus, at the Report Stage of the Bill, this additional legislative competency was

\footnotetext{
112 NI Ass Deb 10 February 2016 vol 112 no 5 p 82.

${ }^{113}$ NI Ass Deb 10 February 2016 vol 112 no 5 p 91.

${ }^{114}$ See eg NI Ass Deb 10 February 2016 vol 112 no 5 p 91

115 Northern Ireland Department of Health and Department of Justice, 'Report of the Working Group on Fatal Fetal Abnormality' (11 October 2016).

${ }^{116}$ Abortion (Fatal Foetal Abnormality) Bill Explanatory and Financial Memorandum (6 December 2016), para 8, at http://www.niassembly.gov.uk/globalassets/documents/legislation/bills/non-executive-bills/session-20162017/abortion-ffa/abortion-ffa-efm-as-introduced---6.12.16.pdf.

${ }^{117}$ BBC News, 'SDLP Members Support Conscience Vote on Abortion Matters' (19 May 2018).

118 HM Government, Cm 8990 (2015), 84.

119 See eg David Mundell, Letter to Bruce Crawford (14 October 2015), at http://www.parliament.scot/2015.10.14 Letter from_S of S to Convener_on Abortion.pdf.
} 
This article has been accepted for publication in the Modern Law Review, and is scheduled to appear in (2019) 82:1.

proposed to be devolved; ${ }^{120}$ this was noted by the Scottish Government in a Legislative Consent Memorandum. ${ }^{121}$ Section 53 of the Scotland Act 2016 thus devolved abortion to the Scottish Parliament; these new powers commenced on 23 May 2016. ${ }^{122}$ The Scottish Parliament is yet to consider primary legislation on this matter.

However, despite being a reserved matter when the Scottish Parliament was created in 1999,123 Scotland has nevertheless long had delegated executive authority over aspects of the law of abortion, as has the Welsh Assembly. These executive authorities were devolved to both constituent nations in a similar manner. In 1999, ministerial functions under sections 1(3) and 2 of the 1967 Act were devolved to the Scottish ministers, and unspecified ministerial functions under the same Act were devolved to the Welsh Assembly. ${ }^{124}$ Both Governments have exercised their powers in this regard on two occasions of importance.

Both Governments have responded to Creasy's proposed amendment to the Queen's speech with a view to allowing Northern Irish women free access to abortion care. In Scotland, the Functions of Health Boards (Scotland) Amendment Order 2017 was made on 19 September 2017 and came into force on 6 November 2017. ${ }^{125}$ Meanwhile, the Welsh Government undertook consultation on the issue and is now considering the responses. ${ }^{126}$ The impact of these changes, compared to the aforementioned legislative reforms proposed at Westminster, can be predicted to be negligible: the Scottish Order's Impact Assessment observed that only 12 abortions had by then been performed in Scotland on women from either Northern Ireland or the Republic of Ireland since 2011, and that 'We estimate that between 20 and 150 women will travel to Scotland each year from Northern Ireland to access abortion services. ${ }^{127}$

The second exercise of executive decision-making of importance has been to allow women to take the second of the two pills administered in early medical abortion by pharmaceutical intervention,

${ }^{120}$ HC Deb 9 November 2015 vol 602 cols 121, 136-161.

${ }^{121}$ Scottish Government, LCM(S4) 37.2 (2016), para 27.

122 On the political discussions had at the time see eg J. Thomson, 'Abortion Law and Scotland: An Issue of What?' (2018) 89 Political Quarterly 100-107.

${ }^{123}$ Scotland Act 1998, Sched 5, s J1. See also Cm 3658, para 3.3. For a criticism of this, see eg D. Stockley, 'The Increasingly Strange Case of Abortion: Scots Criminal Law and Devolution' (1998) 2 Edinburgh Law Review 330337, 332-337.

${ }^{124}$ Scotland Act 1998 (Transfer of Functions to the Scottish Ministers etc.) Order 1999/1750), art 2, Sched 1; National Assembly for Wales (Transfer of Functions) Order 1999/672, art 2(b), Sched 1. On the complexity, loopholes and implications of this devolution, see Taylor and Wilson $\mathrm{n} 14$ above.

125 It is a notable comparison that, in relying on executive rather than parliamentary authority, the Scottish Government has avoided the need to open the debate to Holyrood to the extent which would be required to approve new primary legislation. The Functions of Health Boards (Scotland) Amendment Order 2017 was discussed at a meeting of the Health and Sport Committee because it was an instrument subject to negative review and a motion had been lodged to annul it by Conservative MSP Jeremy Balfour. His concerns related to the instrument's resource implications, the possibility of creating an expansive precedent for other medical treatments not available in Northern Ireland, and the creation of Northern Ireland as a special case. The minister addressed those concerns, expressly drawing a comparison with the UK Government's commitment, and the motion was withdrawn. Scottish Parliament Health and Sport Committee OR (31 October 2017) cols 31-34.

126 Welsh Government WG33314 (2018); Vaughan Gething, Letter to Simon Thomas (29 March 2018) at http://www.assembly.wales/NAfW\%20Documents/Assembly\%20Business\%20section\%20documents/GwyYch 5/GwyYch20180314(2)-en.pdf\#search=\%22northern\%20ireland\%22\%20abortion.

127 Scottish Government, 'Business and Regulatory Impact Assessment: The Functions of Health Boards (Scotland) Amendment Order 2017' (2017); cf Aileen Campbell, who stated that 'The total number of legal abortions performed in Scotland on women who are normally resident in the Republic of Ireland or Northern Ireland during the period 2013 to 2015 was 5.' SP S5W-07621 (31 March 2017). 
This article has been accepted for publication in the Modern Law Review, and is scheduled to appear in (2019) 82:1.

misoprostol, in their own home. The Scottish Government implemented this reform in the Abortion Act 1967 (Place of Treatment for the Termination of Pregnancy) (Approval) (Scotland) 2017, which was signed on 26 October 2017 and allowed such self-administration at the discretion of the prescribing doctor. The impact of this change will be considerable: 73.5 per cent of abortions in Scotland are performed at fewer than nine weeks of gestation, so would be eligible for home administration under the Approval. ${ }^{128}$ Meanwhile, the Welsh Cabinet Secretary for Health and Social Services, Vaughn Gething, signed in June 2018 a like approval, the Abortion Act 1967 (Approval of Place for Treatment for the Termination of Pregnancy) (Wales) 2018. This Welsh approval was verbatim copied from the Scottish precursor. ${ }^{129}$

Whether the Scottish and Welsh Approvals are competent interpretations of the respective ministers' authority is contestable and will be explored elsewhere. ${ }^{130}$ Meanwhile, a judicial review challenge to the Scottish Approval has been raised on different grounds by the Society for the Protection of Unborn Children, the judgement in which is awaited at the time of writing. ${ }^{131}$ Nonetheless, there are wider issues raised here than the competence of any single decision. What this article has shown is that the trend in the law of abortion (as per the general trend in devolution) has been to increase the competency of the devolved bodies of the constituent nations. It has also shown that the powers received by all three of these constituent nations are being exercised; it is not therefore the case that this has been an empty transfer of power.

Those participating in the debates over Westminster's possible intervention in Northern Ireland should therefore be aware that doing so would be contrary to the recent trend of granting increased devolutionary responsibility to Northern Ireland and to Scotland and Wales, and the active assumption of those powers by these constituent nations. A special case might be made for Northern Ireland in that Stormont is not sitting, but this would be both direct rule and knowingly in contravention of the will of the parties which were elected to the Government. This would raise important questions of democratic process in the UK and this is perhaps particularly the case given the divisiveness of the issue of abortion.

\section{THE ROLE OF THE COURTS IN INITIATING FUTURE REFORM}

An additional factor in this discussion is the Westminster Government's obligation to ensure that the UK complies with the European Convention on Human Rights ('the Convention'). In order to ensure that human rights were complied with by the devolved bodies, the legislative powers of the devolved bodies were circumscribed by the requirement that they comply with the Convention Rights. Any legislation enacted by the devolved legislatures can accordingly be challenged in the courts on this basis, and any which is held to be incompatible with the Convention Rights is deemed to be outwith their legislative competence and thus 'not law'. ${ }^{132}$

\footnotetext{
${ }^{128}$ Information Services Division, 'Termination of Pregnancy Statistics, Year Ending December 2016' (2017), 11. 129 Available https://gov.wales/docs/legislation/inforcenonsi/nationalhealth/2018direct56-en.pdf. The only difference in wording is that the Scottish approval talks of 'termination of her pregnancy' whereas the Welsh approval talks of 'termination of pregnancy'.

${ }^{130}$ Taylor and Wilson $\mathrm{n} 14$ above.

${ }^{131}$ On the arguments in court, see R. Taylor and A. Wilson, 'Outer House Arguments over Lawfulness of Abortion Treatment at Home' (18 May 2018) Scottish Legal News, at http://www.scottishlegal.com/article/judiciallyreviewing-the-lawfulness-of-abortion-treatment-at-home-summary-of-arguments-in-the-outer-house.

${ }^{132}$ Scotland Act 1998, s 29(2)(d); Northern Ireland Act 1998, s 6(2)(c); Government of Wales Act 2006, s 81.
} 
This article has been accepted for publication in the Modern Law Review, and is scheduled to appear in (2019) 82:1.

Pre-devolution Acts passed by Westminster which continue to apply to the constituent nations are, by virtue of parliamentary sovereignty, incapable of being struck down by the courts for any incompatibility with Convention Rights. Instead, the Human Rights Act 1998 empowers the courts under section 3 to interpret primary legislation 'so far as is possible' in compliance with the Convention Rights. If this is not possible, the higher courts may instead issue a declaration of incompatibility under section 4; such a declaration does not affect the validity or continuing operation of the legislation it is issued against, but alerts Parliament as to the incompatibility. Parliament may then decide whether or not to remedy the incompatibility with legislation.

There is currently no explicit right to abortion recognised either in the UK or the Convention. However a recent decision of the UK Supreme Court suggests that it might soon recognise a de facto right to abortion in some circumstances under the Convention.

The case in question concerned a judicial review brought by the Northern Ireland Human Rights Commission (NIHRC) challenging the compatibility of the Northern Irish law of abortion with Convention Rights. The Commission sought a section 4 declaration against sections 58-59 of the Offences Against the Person Act 1861 and section 25 of the Criminal Justice Act (Northern Ireland) 1945. The Commission argued that this legislation was incompatible with articles 3 (Prohibition of Torture) and 8 (Right to Respect for Private and Family Life) of the Convention for not excepting abortion in cases of foetal abnormality, rape and incest from criminal prosecution.

At first instance, Horner J in the Queen's Bench Division (Northern Ireland) 'determined that the failure to provide exceptions to the law prohibiting abortion in respect of [fatal foetal abnormalities] at any time and pregnancies due to sexual crime up to the date when the foetus becomes capable of an existence independent of the mother, is contrary to Article 8 of the Convention'. ${ }^{133}$ He therefore issued a declaration of incompatibility with that Article. ${ }^{134}$

That declaration was successfully appealed to the Court of Appeal (Northern Ireland) by the Attorney General of Northern Ireland. Morgan LCJ, Gillen LJ, and Weatherup LJ noted that the Stormont had refused the opportunity to legislate for reform in February 2016. They said therefore that any attempt to contravene that decision would amount to both judicial legislation and a challenge to Stormont's democratic mandate. ${ }^{135}$ The court reversed the declaration of incompatibility and 'left the remedy in the hands of the appropriate legislature for the time being'. ${ }^{136}$

Further appeal by the Commission to the Supreme Court followed, with judgement being rendered on 7 June 2018. ${ }^{137}$ The decision was unusual for a contemporary Supreme Court decision, not only because the Court was deeply divided on both the substantive and procedural questions raised by the case, but because of its approach towards answering them. By a majority of four to three, the Supreme Court dismissed the appeal. The majority (Lord Mance, Lord Reed, Lord Lloyd-Jones and Lady Black) held that the appellants lacked standing because they did not identify any victims or potential victims

\footnotetext{
133 In the Matter of an Application for Judicial Review by the Northern Ireland Human Rights Commission [2015] NIQB 96, para [184]. See also for similar criticisms Northern Ireland Assembly Research and Information Service, 'Briefing Paper: International Human Rights Standards: Recommendations Relating to Northern Ireland' (2016), $25,29,32,41$.

${ }^{134}$ In the Matter of an Application for Judicial Review by the Northern Ireland Human Rights Commission [2015] NIQB 102.

${ }^{135}$ Re Northern Ireland Human Rights Commission's Application for Judicial Review [2017] NICA 42, eg paras [74][75], per Morgan LCJ.

136 ibid para [85], per Morgan LCJ.

${ }^{137}$ Re Northern Ireland Human Rights Commission's Application for Judicial Review [2018] UKSC 27.
} 
This article has been accepted for publication in the Modern Law Review, and is scheduled to appear in (2019) 82:1.

of an 'unlawful act' as required under section 71(2B)(c) of the Northern Ireland Act 1998 in order for the NIHRC to initiate or intervene in 'human rights proceedings'. As a consequence, the Court did not have the jurisdiction to issue a section 4 declaration in this instance. The minority (Lady Hale, Lord Kerr and Lord Wilson), held that the appellants did have standing, and accordingly would have issued a declaration of incompatibility.

When the question of standing is answered in the negative, there is usually no need for the Court to engage with the substance of the legal challenge. ${ }^{138}$ Nonetheless, all of the Justices addressed the issue and offered their own views as to the compatibility of Northern Ireland's abortion law with the Convention rights. A majority (consisting of Lady Hale, Lord Mance, Lord Kerr and Lord Wilson) held that Northern Ireland's abortion law was incompatible with article 8 with respect to the prohibition on abortion in instances of fatal foetal abnormality, rape and incest; Lady Black agreed that the law was incompatible with article 8 in relation to the prohibition on abortion in instances of fatal foetal abnormality abortions only. Lord Kerr and Lord Wilson went further by saying that they would have found the law incompatible with article 3 as well as article 8. Lord Reed and Lord Lloyd-Jones dissented and found no breaches of either article 3 or 8 . Crucially, therefore, a majority of the justices would have issued a section 4 declaration of incompatibility for a breach of article 8 but for the majority decision on standing noted above.

There is a very high likelihood of a new judicial review on the matter by a claimant with standing. ${ }^{139}$ The apparent willingness of the majority of the Justices to issue a declaration of incompatibility makes the finding against Northern Ireland's abortion laws for violation of the Convention rights all but inevitable.

It is submitted that any such decision, by recognising the absence of any exceptions to criminal prosecution for termination of pregnancy as a breach of article 8 , would create a de facto right to abortion in the UK for the very first time under the Convention, albeit a limited one. The consequences of such a finding could have a profound effect on the future trajectory of abortion law across the entire UK, potentially shifting responsibility in the abortion debate away from politicians and closer to judges. Disagreement over the appropriateness of such a shift was reflected in the comments of Lord Reed, Lady Hale and Lord Kerr, thus highlighted the on-going tension at the heart of the UK Constitution between law and politics which continues to dominate contemporary debate. ${ }^{140}$

Given the Court was divided on all issues raised in the case, there is accordingly no 'single lead judgment which represents the majority view on all issues'. ${ }^{141}$ It is, however, instructive to look further at the comments of two of the Justices, Lord Reed and Lady Hale. These are clearly indicative of the controversial and contentious nature of the subject matter at issue. As Lord Reed noted in his dissenting judgment, 'It is difficult to envisage a more controversial issue than the proper limits of the law governing abortion. Diametrically opposed views, and every shade of opinion in between, are held

\footnotetext{
138 ibid [334], per Lord Reed.

${ }^{139}$ Following the Supreme Court's decision, Sarah Ewart, an intervener in the case, indicated that she intends to challenge the lawfulness of the law in the High Court of Justice in Northern Ireland. See https://www.bbc.co.uk/news/uk-northern-ireland-44402908.

${ }^{140}$ For more on this, see R. Taylor, 'The Contested Constitution: An Analysis of the Competing Models of British Constitutionalism' [2018] Public Law 500.

${ }^{141}$ Re Northern Ireland Human Rights Commission's Application for Judicial Review n 135 above, [4], per Lady Hale.
} 
with equal sincerity and conviction. Each side of the debate appeals to moral or religious values which are held with passionate intensity. ${ }^{142}$

In his view, the legislature is the 'the natural place' for abortion debate to be resolved, ${ }^{143}$ and not the courts, who have only a limited role to play. ${ }^{144}$ When considering the compatibility of Northern Ireland's abortion laws with the Convention rights, Lord Reed emphasised that the Court's role in the determination of the question is 'strictly limited'. ${ }^{145}$ Because the role of national legislatures in defining the limits of article 8 had been recognised at the European level, ${ }^{146}$ Lord Reed argued that national courts must likewise 'respect the importance of political accountability for decisions on controversial questions of social and ethical policy'. ${ }^{147}$ As Lord Reed noted:

The Human Rights Act and the devolution statutes have altered the powers of the courts, but they have not altered the inherent limitations of court proceedings as a means of determining issues of social or ethical policy. Nor have they diminished the inappropriateness, and the dangers of the courts themselves, of highly contentious issues in social and ethical policy being determined by the judges, who have neither any special insight into such questions nor any political accountability for their decisions. ${ }^{148}$

Consequently, despite recognising that a violation of the Convention rights as a result of Northern Ireland's laws was likely to occur should the law remain unchanged, ${ }^{149}$ Lord Reed nevertheless felt that abortion, especially when being considered in the abstract, required the determination of 'highly sensitive and contentious questions of moral judgment' that are 'pre-eminently matters to be settled by democratically elected and accountable institutions'. ${ }^{150}$ The courts, he argued, should not 'preempt democratic debate on changes to the law ... to take the matter out of the hands of democratically accountable institutions. ${ }^{151} \mathrm{He}$ therefore expressed a desire that the Northern Irish Assembly's aforementioned review of the law of abortion which halted in January 2017 would soon be completed, ${ }^{152}$ a sentiment shared by Lady Black. ${ }^{153}$

However, Lady Hale and Lord Kerr clearly disagreed with Lord Reed over the level of deference that should be accorded the legislature in in the exercise of the court's judicial functions. Irrespective of whether or not the UK is accorded a wide margin of appreciation on the issue, ${ }^{154}$ Lady Hale argued, Parliament does not enjoy exclusivity in deciding 'what is, or is not, compatible with Convention rights'. ${ }^{155}$ As she notes, 'It is a matter of fundamental human rights on which, difficult though it is, the courts are as well qualified to judge as is the legislature. In fact, in some ways, the courts may be thought better qualified, because they are able to weigh the evidence, the legal materials, and the

\footnotetext{
142 ibid [336], per Lord Reed.

143 ibid [336], per Lord Reed.

144 ibid [337], per Lord Reed.

145 ibid [337], per Lord Reed.

147 ibid [344], per Lord Reed.

148 ibid [344], per Lord Reed.

149 ibid [363], per Lord Reed.

150 ibid [362], per Lord Reed.

151 ibid [364], per Lord Reed.

152 ibid [363], per Lord Reed.

153 ibid [370], per Lady Black.

154 ibid [36], per Lady Hale.

155 ibid [37]-[38], per Lady Hale.
}

146 ibid [343], per Lord Reed. He also noted that the European Court of Human Rights had never interpreted the Convention as requiring states to introduce abortion of any kind, recognising abortion as a matter better left to national authorities for determination: ibid [345]. 
arguments in a dispassionate manner, without the external pressures on which legislators may be subject. ${ }^{\prime 156}$

Lord Kerr placed great significance on the fact that the Northern Irish Assembly has yet to make a decision on reforming the law of abortion in Northern Ireland. ${ }^{157}$ He concluded that there is accordingly no usurpation by the courts of the functions of the decision-maker in this instance, and the courts 'should feel no inhibition in relation to the question of whether the current law offends article 8 of the Convention, in the light of the absence of any firmly expressed view of the democratic institutions of Northern Ireland'. ${ }^{158}$

Furthermore, Lady Hale emphasised the fact that 'Parliament has expressly given the higher courts the power to rule upon the compatibility or incompatibility of legislation with the Convention rights', and that 'Parliamentary sovereignty is respected, not by our declining to make a declaration, but by what happens if and when we do'. ${ }^{159}$ Indeed, if a section 4 declaration of incompatibility had been issued, Northern Ireland's abortion laws would not have changed automatically; the choice of whether or not to change the law in order to make it compatible remains with Parliament.

Lady Hale is correct when she says that 'All that a declaration of incompatibility does ... is place the ball in Parliament's court'. ${ }^{160}$ However, Parliament has only failed to change the law in response to a declaration of incompatibility once since the Human Rights Act came into force. ${ }^{161}$ It is implausible that failure to address any future section 4 declaration could happen again in respect to Northern Ireland's abortion laws. Parliament and the UK Government would accordingly have to take express legislative action on abortion for the first time, thus marking a dramatic change in direction from past practice, where change has mostly been driven by backbench PMBs.

Furthermore, any changes introduced by Parliament would need to correct the incompatibility identified by the issuing Court. The impetus for change, therefore, will not have originated from democratic debate, but instead from legal action. Given that the legislative competences of the devolved bodies are expressly limited by the Convention rights, legislative reform of Northern Ireland's abortion laws by Westminster at the behest of the courts may counter any claims that Westminster are interfering with the affairs of Northern Ireland contrary to the spirit of the devolved settlement.

However, by issuing any such declaration of incompatibility, thus recognising a de facto breach of a right to abortion under article 8 , the courts would be setting a minimum standard for abortion law across the whole UK. This would bring greater uniformity to the law of abortion, which it is submitted could undermine the purpose of granting legislative powers on abortion to the devolved nations in the first place-especially so in the case of Northern Ireland. As Stockley notes, 'The very existence of devolution - regardless of the pre-existing differences in the legal system - is based on a recognition of distinct communities with differing needs and desires. ${ }^{162}$ In reality, the issuing of a declaration means that the constituent nations can likely only extend what constitutes a lawful abortion rather than restrict such a definition (at least beyond a certain point). They further do not necessarily have the discretion not to act in certain circumstances; this is in contrast to Westminster. It is acknowledged

\footnotetext{
156 ibid [38], per Lady Hale.

157 ibid [291]-[295], per Lord Kerr.

158 ibid [295], per Lord Kerr.

159 ibid [39], per Lady Hale.

160 ibid [40], per Lady Hale.

${ }^{161}$ Smith v Scott [2007] CSIH 9.

162 Stockley n 121 above, 333. See also 334.
} 
that the constitutions of the devolved bodies are internally constrained by the Human Rights Act. Despite this, it is nevertheless submitted that this could put the devolutionary settlement in conflict with the Human Rights Act: although one of the purposes of devolution was to permit national variations on particular matters, this purpose may be frustrated by the underlying aim of the Human Rights Act, namely to ensure consistent compliance with the Convention Rights across the entire UK.

\section{CONCLUSION}

This article has examined the reforms recently and currently under consideration by all four of the UK's legislatures. It has shown that the legislative intentions of the Bills introduced in Westminster are contradictory. The discussion on-going in the House of Commons is largely focused on making abortion more accessible, whereas the current law reform attempts in the House of Lords have been to restrict access to abortion. It is unlikely that any of these Bills will progress into law during this parliamentary session, given the press of other business and especially given the political volatility caused by a slim governmental majority.

Irrespective of these unusual circumstances, this article has shown that the parliamentary rules of the two Houses of Parliament make the enactment of PMBs unlikely. This legislative challenge is particularly relevant to the law of abortion, which has traditionally been an area where reform has been proposed by PMB rather than Government Bills. Should the current Bills fail to progress, questions may be asked why Bills to reform the law of abortion should again lack proper examination in Westminster. This article has submitted that (regardless of one's view of abortion) full, open and informed debate of legislative reform is required for the exercise of democratic rule.

Meanwhile, the devolutionary settlements are, as has been shown, inconsistent with respect to the timing, extent and clarity of devolving of competence in the law of abortion. However, what is consistent is that all three constituent nations have exercised their devolved functions, either through consideration of primary legislation (in the case of Northern Ireland) or through executive actions (in the case of Wales and Scotland).

The recent move towards liberalisation advocated in the House of Commons is in keeping with law reforms in Scotland and Wales to make abortion more accessible. However the extension of Westminster's liberalising intention to Northern Ireland is politically and legally complex. It may add to the Prime Minister's difficulties if she were to concede to liberalise Northern Irish law while members of her own party were sponsoring legislation to make abortion unavailable to women in England and Wales who have access under the current legislative framework. Such a move would also be contrary to the most recent expression of legislative intention of Stormont.

However, the recent Supreme Court judgement suggests that, far from being a 'matter of conscience' to be determined by politicians specific to each nation, abortion is, or soon will be, a matter of law to be determined in part by judges in light of human rights obligations. This would represent a change in the court's approach to abortion cases: it has previously interpreted the legislation in a technical rather than rights-focused manner, such as in Doogan. ${ }^{163}$ The question becomes whether or not the courts' rulings on those rights is the correct one. The determination of that, however, will rest with Parliament as it considers whether to address any future declaration of incompatibility.

\footnotetext{
163 n 13 above.
} 